\title{
Beden Eğitiminde İhtiyaç Destekleyici Öğretim Stili Ölçeğinin Türkçeye Uyarlanması ${ }^{1}$
}

\section{Adaptation of the Need Supportive Teaching Style Scale for Physical Education to Turkish}

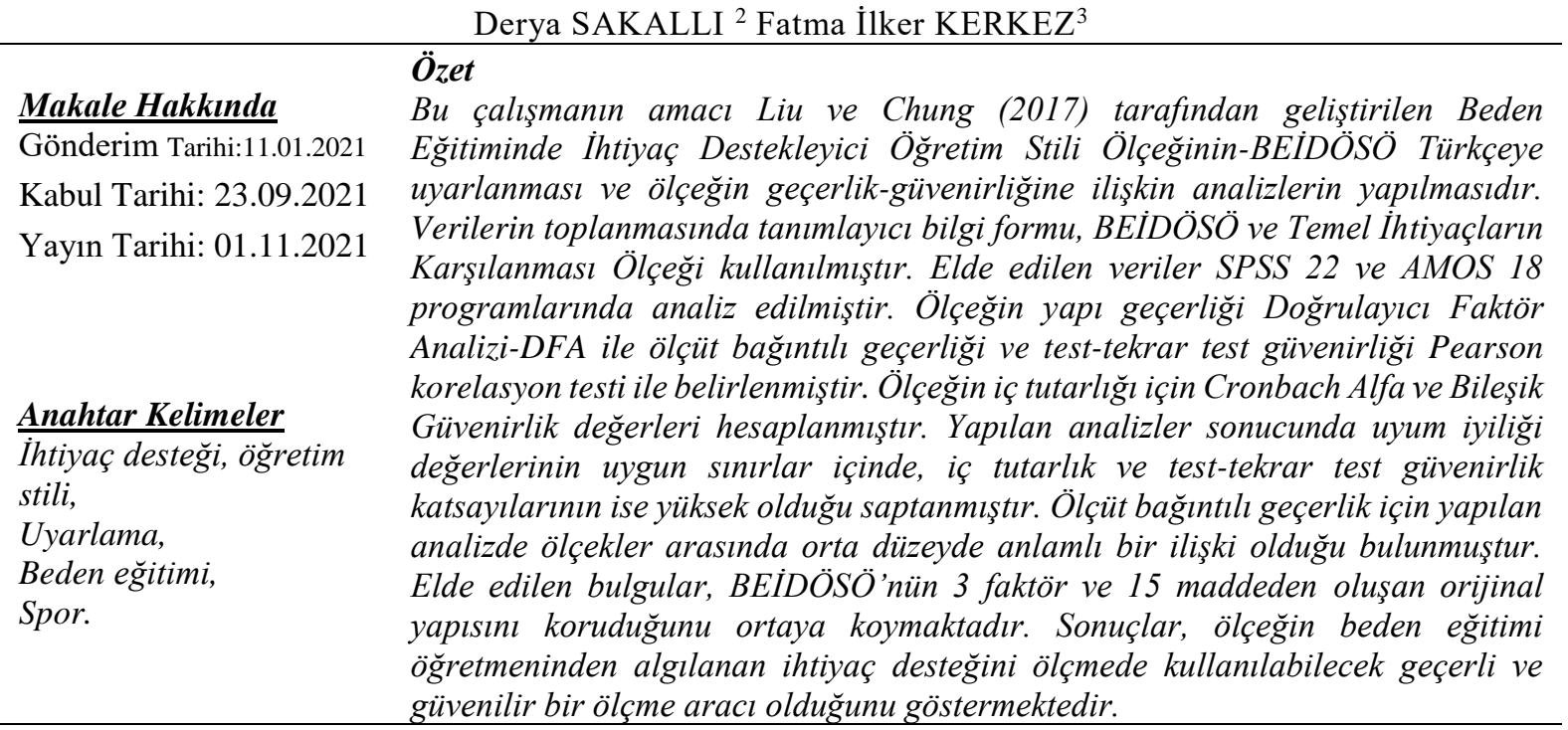

\section{Abstract}

The aim of this study was to adapt the Need-Supportive Teaching Style Scale in Physical Education-NSTSSPE to Turkish language which was developed by Liu

\section{Key Word}

Need support, teaching style, adaptation, physical education, sport. and Chung (2017) and to analyze validity and reliability of the scale. Descriptive information form, NSTSSPE, Basic Psychological Needs Scale were used to collect data. The obtained data were analyzed in SPSS 22 and AMOS 18. The construct validity of the scale was determined by Confirmatory Factor Analysis-CFA, criterion validity and test-retest reliability were determined by Pearson correlation test. Cronbach Alpha and Composite Reliability values were calculated for the internal consistency of the scale. As a result of the analysis, it was determined that goodness-of-fit indices were within the appropriate limits, internal consistency and test-retest reliability coefficients were found to be high. Criterion validity analysis showed that there was a moderately significant relationship between the scales. Findings revealed that NSTSSPE maintains its original structure consisting of 3 factors and 15 items. The results showed that the scale is a valid and reliable measurement tool that can be used to measure the middle school students' perception of teaching style of their physical education teacher.

Atıf için:

For Citation
Sakallı, D. \& İlker Kerkez, F. (2021). Beden eğitiminde ihtiyaç destekleyici öğretim stili ölçeğinin Türkçeye uyarlanması. Muğla Sitkı Koçman Üniversitesi Eğitim Fakültesi Dergisi [MSKU Journal of Education], 8(2), 655-673. DOI: 10.21666/muefd.858465

\footnotetext{
${ }^{1} \mathrm{Bu}$ çalışma birinci yazarın yüksek lisans tezinden türetilmiş ve 13- 16 Kasım 2019 tarihinde 17. Uluslararası Spor Bilimleri Kongresinde sözel bildiri olarak sunulmuştur.

${ }^{2}$ Muğla Sıtkı Koçman Üniversitesi Spor Bilimleri Fak. deryasakallii@gmail.com, ORCID: 0000-0001-9039-9905

${ }^{3}$ Muğla Sitkı Koçman Üniversitesi Spor Bilimleri Fak. fatmakerkez@mu.edu.tr, ORCID: 0000-0002-5485-1834
} 
Eğitim, bireyin doğumundan ölümüne kadar yaşamının her alanını etkileyen bir süreçtir. Bireyi ve birey aracılığıyla toplumu dönüştüren eğitim, toplumların geleceğinin şekillenmesinde oldukça önemlidir (Memduhoğlu ve Yılmaz, 2019). Bu sebeple eğitimin amacı akademik başarının elde edilmesinden ziyade bireylerin entelektüel ve kişisel gelişimlerini desteklemek olmalıdır (Ryan ve Deci, 2017).

Eğitim sürecinde yer alan ve öğrenmeyi etkileyen pek çok faktör vardır. Eğitim araştırmalarının odaklandığı temel konu, bu faktörlerin öğrenci başarısını nasıl etkilediğini tanımlamak ve anlamaktır. Çünkü bu sayede öğrenmenin teşvik edildiği ortamlar yaratılabilir veya öğrenmeyi engelleyebilecek faktörler belirlenerek ortadan kaldırılabilir (Subramaniam ve Silverman, 2007). Sinıflar, öğrencilerin ihtiyaçları, hedefleri, ilgi alanları ve değerlerini destekleyen ya da engelleyen sosyal ortamlardır. $\mathrm{Bu}$ ortamlarda öğrenme sürecine katılım, öğrencinin kendi motivasyonu ile sınıftaki destek ya da engellerin ortak bir ürünü olarak ortaya çıkmaktadır. Bu nedenle sınıflarda, öğrenci motivasyon ve katılımını destekleyici koşullara, özellikle de destekleyici öğrenci-öğretmen ilişkilerine ihtiyaç duyulmaktadır (Reeve, 2012). Çünkü sınıf iklimine katkıda bulunan en önemli faktör öğretmenin öğrencilerle olan iletişim şeklidir (Ryan ve Deci, 2017).

Son yıllarda, öğretmenlerin kişilerarası iletişim tarzı ve davranışları Öz Belirleme Kuramı (ÖBK) çerçevesinde ele alınmaktadır (Liu ve Chung, 2017). ÖBK, öğretim davranışı ve öğrenci motivasyonu ile ilgili önemli araştırmalar için teorik bir çerçeve işlevi görmektedir (De Meyer vd, 2014). Özbelirleme, kişinin kendi yaşamının sorumluluğunu alması ve buna dayanarak özgür seçimler yapması anlamına gelmektedir (Kandemirci, 2018). Kuram, kişilik gelişimi, öz düzenleme, psikolojik ihtiyaçlar, yaşam hedefleri, enerji ve canlılık, bilinçdışı süreçler, kültür-motivasyon ilişkisi ve sosyal çevrenin motivasyon ve davranış üzerine etkileri gibi konuları ele almaktadır. Diğer kuramlar gibi motivasyon miktarına odaklanmak yerine, motivasyonun türü ve kalitesinin çeşitli sonuçlarla ilişkisini incelemekte ve içsel-dışsal motivasyon arasındaki ayrımı ortaya koymaktadır (Deci ve Ryan, 2008).

Motivasyon; davranışa enerji veren, davranışı yönlendiren ve sürekliliğini belirleyen içsel bir durum olarak tanımlanmaktadır (Hagger ve Chatzisarantis, 2007). Kurama göre doğuştan gelen temel bir güç olan motivasyon bireysel, bilişsel ve kültürel faktörlerin etkisiyle içsel ve dışsal olarak iki farklı şekilde ortaya çıkmaktadır (Tekinalp ve Terzi, 2015). İçsel motivasyon, bireylerin bizzat aktivitenin kendisini ödül olarak görmesi ve bu aktivitelere katılımdan mutlu olması anlamına gelir. Dışsal motivasyon ise, davranışın bir ödül kazanmak ya da bir cezadan kaçınmak için gerçekleştirilmesidir (Zencirkıran, 2017). Kuramda ayrıca doğuştan gelen ve çevreyle etkileşimler sonucu ortaya çıkan çeşitli ihtiyaçlardan söz edilmektedir (Deci ve Ryan, 1985). Buradaki ihtiyaç kavramı, psikolojik gelişme, bütünlük ve iyi oluş için gerekli yapı maddeleri olarak tanımlanır (Ryan ve Deci, 2007; Deci ve Ryan, 2012). ÖBK'nin merkezinde yer alan bu ihtiyaçlar özerklik (autonomy), yeterlik (competence) ve ilişkili olma (relatedness) olarak adlandırılır. Kurama göre bireyler bu üç temel psikolojik ihtiyacı karşılamak için davranışta bulunurlar (Hagger ve Chatzisarantis, 2007). ÖBK'ye göre, sosyal bağlamlar psikolojik ihtiyaçları destekleyerek ya da engelleyerek bireyleri etkiler. Söz konusu ihtiyaçlar karşılandığı ölçüde sağlıklı gelişim gerçekleşmekte, karşılanmaması durumunda çeşitli psikolojik zararlar ortaya çıkmaktadır (Deci ve Ryan, 2012).

Özerklik ihtiyacı, bireyin kendi çıkarları ve değerleri doğrultusunda hareket etme ihtiyacını temsil eder (Rocchi, Pelletier, Cheung, Baxter ve Beaudry, 2017). Özerklik; davranışların kişinin gerçek ilgi ve değerleri ile uyumlu olmasıdır. Davranışların benlik tarafından düzenlenmesine ilişkindir, canlılık hissi ve bütünlük deneyimleri ile bağlantılıdır (Ryan ve Deci, 2017). Başka bir ifadeyle kişinin davranışlarıyla ilgili dışsal kısıtlamalardan uzak olması (Seifert ve Sutton, 2009) ve kendi seçimleriyle hareket etmesidir. Davranış özerk olduğunda bireyler düşünce, duygu ve davranışlarının birbiriyle uyumlu olduğunu hissederler (Weinstein ve DeHaan, 2014).

Yeterlik ihtiyacı; sosyal çevreyle olan etkileşimlerde etkili hissetme ihtiyacı anlamına gelmektedir (Stroet, Opdenakker ve Minnaert, 2013). Bu ihtiyaç etkinlik, kabiliyet, uygunluk ve başarının bir koşulu olarak görülmektedir (Elliot, Dweck, Yeager, 2017). Başka bir tanıma göre yeterlik; kişinin bir iş yapmak için gereken güce ve yeteneğe sahip olduğunu hissetmesi, başarılı olabileceğine ve başarabileceğine inanmasıdır (Cihangir-Çankaya, 2005).

İlişkili olma ihtiyacı, kişinin sosyal alanındaki diğerleriyle yakın ve bağlı hissetmesi, başkalarını önemsemesi ve başkaları tarafından da önemsendiğini hissetmesi anlamına gelmektedir. İlişkili olma, bireyin diğer önemli kişilerle güvenli ve tatmin edici ilişkilere sahip ve değerli gruplara ait olma 
duygusuna da yansımaktadır (Weinstein ve DeHaan, 2014). Bu ihtiyaç, kişilerarası güçlü ilişkiler ile birlikte, destekleyici ve ilgili sosyal bir ortama duyulan ihtiyac1 da ifade etmektedir (Rocchi vd, 2017). ÖBK'ye göre bireysel gelişimin en önemli noktası özerklik, yeterlik ve ilişkili olma olarak adlandırılan temel psikolojik ihtiyaçların karşılanmasıdır. Bu ihtiyaçların sosyal çevre tarafından desteklenmesi ve ihtiyaç doyumunun sağlanması durumunda bütünleşme gerçekleşmekte, engellenmesi durumunda ise iyi oluş ve öz düzenleme azalmaktadır (Cihangir-Çankaya 2005). Bu nedenle, eğitim ortamlarının ögrencilerin farklı ilgi alanlarına ve kapasitelerine destek verecek şekilde düzenlenmesi ve temel psikolojik ihtiyaçlarının karşılanmasına özen gösterilmesi önemlidir (Ryan ve Deci, 2017). Kuramda temel ihtiyaçların karşılanması ve engellenmesi ile ilgili altı farklı öğretim stilinden söz edilmektedir. Bunlar özerklik destekleyici-denetleyici (autonomy supportive - controlling), yeterlik destekleyiciyeterlik engelleyici (structure - chaotic) ve bağl1lık-bağl1lık engelleyici (involvement - cold behavior) ögretim stilleri olarak adlandırılmaktadır (Skinner ve Belmont, 1993).

Eğitim ortamında öğrencilerin özerk hissetmeleri için, öğrenme sürecine katılımı kendi ihtiyaç ve değerlerini yansıtan, kendi seçtikleri bir eylem olarak deneyimlemeleri çok önemlidir (Stroet vd, 2013). Özerklik destekleyici öğretim stilinde (ÖDÖS), öğrencilere mümkün olduğunca çok seçenek sunulmas1 (Deci ve Ryan, 2016; Ryan ve Deci, 2017; Seifert ve Sutton, 2009) ve bilgilendirici geri bildirimler verilmesi gerekmektedir (Reeve ve Jang, 2006). Ayrıca öğretmenlerin öğrencilerin kişisel ilgi ve ihtiyaçlarına uygun zorluklar yaratılması, konuyla alakalı ve ilgi çekici faaliyetler hazırlaması önemlidir (Jang, Reeve ve Deci, 2010). Bu stili kullanan öğretmen, öğrencilerin kendi kararlarını vermelerine ve problem çözmeleri için sorumluluk almalarına izin vermeli (Bailey, Cope ve Pearce, 2013), öğrencilerini dinlemeli ve sorularına cevap vermeli, onlara yeni şeyleri keşfetme ve deneme firsatları sunmalıdır (Hagger ve Chatzisarantis, 2007). Öğretmenler, öğrencilerin farklı düşünce ve duygularını kabul etmeli, bir davranışı kendi kendilerine başlatmalarını teşvik etmeli, sınırlar olması durumunda bu sınırlar için anlamlı gerekçeler sunmalı, denetleyici ifadelerin kullanımından (Niemiec, Soenens ve Vansteenkiste, 2014) ve öğrenci performanslarını karşılaştırmaktan kaçınmalıdır. Not gibi dışsal ödülleri en aza indirmeli, öğrencileri kendi hedef ve ilgi alanları doğrultusunda yönlendirmelidir (Seifert ve Sutton, 2009). Bu stil; öğrencilerde içsel motivasyonu, devamlılı̆̆ 1 ve öğrenme kalitesini artırmakta (Ryan ve Deci, 2017), daha olumlu öğrenme deneyimlerini ve performansı açığa çıkarmaktadır (Deci ve Ryan, 2016). Denetleyici öğretim stili, ÖDÖS'nin tersini ifade etmektedir. Bu stil, öğretmenin öğrenme materyallerini elinde bulundurması, öğrencilerin kendilerini ifade etmelerine yeterince zaman vermeden cevapları söylemesi, öğrencileri sıkıcı ya da anlamsız buldukları şeyleri yapmaya zorlaması, öğrenme etkinliklerini dışsal hedeflere bağlaması ve öğrencilerin farklı fikirleri ifade etmelerine izin vermemesi gibi davranışlarla gözlenmektedir (Stroet, Opdenakker ve Minnaert, 2015).

Yeterlik destekleyici öğretim stili (YDÖS), öğretmenlerin başarıyı, anlamlı öğrenmeyi ve beceri gelişimini teşvik eden bir sosyal öğrenme ortamını ne kadar iyi üretebildiklerine odaklanır (Otundo ve Garn, 2019). Yeterlik ihtiyacının desteklenmesi için; öğrencilerin aktif olarak öğrenme sürecine katılabileceği aktiviteler sunmak, öğrencilere mümkün olduğunca kısa sürede cevap vermek (Seifert ve Sutton, 2009), zor ancak aşırı derecede zor olmayan görevler hazırlamak oldukça önemlidir (Weinstein ve DeHaan, 2014). Bu stilde öğretmenler, açık ve tutarlı kurallar koymalı, rehberlik sağlamalı, ihtiyaçları olduğunda öğrencileri için ulaşılabilir olmalı ve başarının doğuştan gelen yeteneklerden ziyade çoğunlukla içsel olarak kontrol edilebilir faktörlere bağlı olduğu düşüncesini teşvik etmelidir (Stroet vd, 2015). Ayrıca öğretmenler, derse ilişkin beklentilerini açıkça bildirmeli, ihtiyaç olması durumunda destek sağlamalı, gelecek derslere ilişkin taslak sunmalı ve gereksiz bilgiler vermekten kaçınmalıdır (Aelterman, Vansteenkiste, Berghe, De Meyer ve Haerens, 2014). Diğer taraftan öğrencinin yeterliği, başarıya karşı olumlu tutum sergileme, başarı önündeki engellerin belirlenmesi amacıyla konuşma yapma, beceri gelişimi ve problem çözme konusunda yardımcı olma, açık, tutarlı ve makul kurallar belirleme ile desteklenebilmektedir (Niemiec vd, 2014). YDÖS'de olumlu, yapıc1, anında ve doğru geribildirimlerin verilmesi de oldukça önemlidir (Aelterman vd, 2014; Niemiec vd, 2014; Ryan ve Deci, 2017; Stroet vd, 2015; Weinstein ve DeHaan, 2014). Yeterlik engelleyici öğretim stili, öğretmenlerin bir görev yönetimine ilişkin öğrenci sorularını cevaplamak için müsait olmaması, rekabetçi öğrenme yapılarını ve öğrenme etkinliklerindeki başarının çabadan ziyade doğuştan gelen yeteneklere bağlı olduğu düşüncesini teşvik etmesi, öğrenci performanslarını değerlendirmeye odaklanan kıyaslayıcı geribildirimler sunması ile gözlenmektedir (Stroet vd, 2015).

İlişkili olma ihtiyacı; okul iklimi ve öğrenci-öğretmen arasındaki ilişkinin kalitesini ifade etmektedir. Aidiyet, kabul, önem ve kişilerarası destek gibi duygular, öz-yeterlik, başarı beklentileri, başarı 
değerleri, olumlu etki, çaba, katılım, okula ilgi, görev yönelimi ve okul notları gibi önemli akademik sonuçlarla ilişkilendirilmektedir. Bu ihtiyacın desteklenmesinde, potansiyel bir bağlanma figürü, pedagog, disiplin sağlayıcı ve öğrenci performansının belirleyicisi olarak öğretmenlerin öğrenciler ile ilişkileri özellikle etkilidir (Furrer ve Skinner, 2003). Eğitim ortamında bağl1lık öğretim stiline (BÖS) karşı1ık gelen ilişkili olma ihtiyacı, öğretmenlerin kişilerarası olumlu ilişkileri kolaylaştıran bir sosyal ögrenme ortamını ne kadar iyi üretebileceğine odaklanmaktadır (Otundo ve Garn, 2019). Bu ihtiyaç, öğrenciye karşı sıcak, empatik ve yargılayıcı olmayan bir duruş sergileyerek, ona saygı duyarak, ilgi göstererek ve koşulsuz destek vererek karşılanmaktadır (Niemiec vd, 2014). Bağl1lık stilinde öğrencilerin birlikte çalıştıkları, destekleyici, öğrenci çeşitliliğini sağlayan ve bireyler arasındaki rekabeti en aza indiren faaliyetlerin düzenlenmesi, öğrencilere özen gösterilmesi, onlarla ilgilenilmesi, onlara işbirliği gerektiren ödev ve faaliyetlerin verilmesi gerekmektedir (Seifert ve Sutton, 2009). Öğretmenin öğrencilerine zaman ayırması, sevgi göstermesi ve onları anladığını hissettirmesi de önemlidir (Stroet vd, 2013). Stili kullanan öğretmen; öğrencilerine sevgi göstermekte ve onlarla ilgilenmektedir, sınıfta empatiyi ve olumlu sosyal davranışları teşvik eden öğretmen, ihtiyaç olması halinde tüm öğrencileri için ulaşılabilir durumdadır. Bağl1lık engelleyici öğretim stili ise, öğretmenlerin ögrencileriyle samimi olmayan bir şekilde konuşmaları, öğrencilerine yeterince ilgi göstermemeleri, tutarsız davranmaları, tüm öğrenciler için müsait olmamaları gibi davranışlarla gözlenmektedir (Stroet vd, 2015).

Günümüz eğitim politikaları genellikle test sonuçlarına ve belirli alanlardaki öğrenci performansına odaklanmasına rağmen, daha kaliteli öğrenme çıktıları ve kişisel gelişim için temel psikolojik ihtiyaçların desteklendiği eğitim ortamlarına ihtiyaç duyulmaktadır (Liu, Wang ve Ryan, 2016). Yapılan çalışmalar psikolojik sağlık ve iyi oluş açısından gerekli olan temel ihtiyaçların desteklenmesiyle bireylerin daha organize, bütünleşmiş ve uyumlu olduğunu, karşılanmaması ya da engellenmesi durumunda ise çeşitli olumsuz sonuçların ortaya çıtığını göstermektedir (Weinstein ve DeHaan, 2014). İhtiyaç destekleyici öğretim stili, öğretmenlerin öğrenci motivasyonunu artırmaları için kullanabilecekleri güçlü bir araçtır (Cañabate, Colomer ve Serra, 2018). Bu stil, öğrencilerin özerklik, yeterlik ve ilişkili olma ihtiyaçlarının karşılanmasını sağlamakta, sağlıklı yaşam davranışları sürdürmede gerekli olan motivasyonun ve öz düzenleme becerisinin artırılmasına yardımcı olmaktadır (van Dongen vd, 2018). Diğer taraftan ihtiyaç destekleyici öğretim stili ile derse katılım arasında pozitif ilişki varken, ihtiyaç engelleyici stil öğrencilerin desten uzaklaşmasına sebep olmaktadır (Berghe, Cardon, Tallir, Kirk ve Haerens, 2016). Ayrıca özerklik destekleyici öğretim stili ve farkındalık, temel psikolojik ihtiyaçların doyumu ile pozitif, ihtiyaçların engellenmesi ile negatif ilişkilidir (Li vd, 2019). Öğrencilerin özerklik destekleyici öğretim stili algıları ile öznel zindelikleri ve ihtiyaç doyumlarının, denetleyici öğretim stili algılarıyla negatif duygu durumları ve ihtiyaçların engellenmesinin ilişkili olduğu saptanmıştır (Liu, Bartholomew ve Chung, 2017).

Öğrencilerin sağlıklı gelişimi; gelişim özelliklerine uygun, çok iyi hazırlanmış ve nitelikli bir eğitim görmelerine bağlıdır. Çağdaş eğitim anlayışına uygun olarak eğitimdeki amaçlara ulaşabilmek için, zihinsel ve fiziksel eğitimin birlikte verilmesi gerekir (Güneş, 2004). Genel eğitimin ayrılmaz bir parçası olan beden eğitimi dersi, öğrencilerin fiziksel, zihinsel, sosyal ve duyuşsal alanlarda gelişimlerine katkı sağlamaktadır (Acar, 2012; Esen, 2010). Beden eğitimi dersinde öğrencilerin fiziksel aktiviteye katılım açısından içsel olarak motive olmalarını sağlayacak öğrenme deneyimleri yaşatmak oldukça önemlidir. Ayrıca dersin amacı öğrencilerin spor ve fiziksel aktiviteye katılımlarını yaşam boyunca sürdürmek istemelerini sağlamaktır (Hastie, Rudisill ve Wadsworth, 2013). Bu amaçlara ulaşılmasında öğrenci, okul, öğretmen ilişkisinin önemi büyüktür. Özellikle öğretmenlerin, öğrencilerin dersi ve sporu sevip yaşam tarzı haline getirmeleri, dolayısıyla toplumun spora bakış açısını oluşturmada önemli bir misyonlar1 vardır (Acar, 2012).

Ortaokul dönemi, bireylerin sağlıklı yaşam alışkanlıkları oluşturmaları için kritik bir kavşaktır. Beden eğitimi dersi, öğrencilere yapılandırılmış, okul temelli bir öğrenme ortamında sağlıklı yaşam hakkında bilgi edinme firsatı sunar. Ne yazık ki, bu dönem öğrencilerin beden eğitimine yönelik olumlu tutumlarının azalmaya başladığı bir dönemi temsil etmektedir (Mercier, Donovan, Gibbone ve Rozga, 2017). Ülkemizde yapılan çalışmalar da öğrencilerin beden eğitimi dersini sevdiklerini, ancak spor yapma alışkanlığı kazanmadıklarını (Orhan ve Yoncalık, 2016), derse karşı olumlu tutum göstermelerine rağmen, okul dışı fiziksel aktivitelere yeterince katılmadıklarını göstermektedir (Esen, 2010). Ayrıca ülkemizdeki öğrencilerin fiziksel aktiviteye katılım düzeyleri diğer ülkedeki çocuklardan daha düşük seviyededir (Bayrakdar, 2010). 
Sağlığın ve iyi oluşun artırılması için önemli bir kaynak olan önemli beden eğitimi dersinde çocukların ihtiyaçlarını karşılayacak firsatlar yaratmak oldukça önemlidir (Curran ve Standage, 2017; Ryan ve Deci, 2017). Bu nedenle öğrencilerin algıladıkları ihtiyaç desteğinin belirlenmesinin oldukça önemli olduğu düşünülmektedir. Literatürde, çeşitli kademelerde öğrenim gören öğrencilerin öğretmenlerinden algıladıkları ihtiyaç desteğini ölçmeyi hedefleyen ölçekler mevcuttur. Ancak, algılanan ihtiyaç desteğini ölçmek için kullanılan bir ölçüm aracında yalnızca olumlu ifadelerin bulunması önerilmektedir. Çünkü ihtiyaç destekleyici ve engelleyici olarak tanımlanan öğretim stilleri tamamen zıt kavramlar değildir. Bir öğretmen tarafından her iki stil de aynı anda ve farklı düzeylerde kullanabilmektedir (Bartholomew, Ntoumanis ve Th $\oslash$ gersen-Ntoumani, 2009). Kurama göre öğretmenlerin öğrencileri motive etme stilleri birbirlerinden farklıdır. Kavramsal olarak ayırt edilebilen destekleyici ve engelleyici stiller, eğitim ortamında farklı derecelerde ortaya çıkabilir (Haerens vd, 2018). Diğer taraftan engelleyici öğretim stili her zaman negatif bir anlam taşımamaktadır. Destekleyici ya da engelleyici stiller, ögrencilere destek sağlamada birbirinin alternatifi olarak kullanılabilmektedir (Chua, Wong ve Koestner, 2014). Ölçeklerde hem olumlu hem de olumsuz ifadelere yer verilmesi, algılanan desteğin ölçülmesinde hatalı sonuçlara neden olabilmektedir. Bunun nedeni, olumlu ifadelerin olduğu gibi, olumsuz ifadelerin de ters kodlanmasıdır. Olumsuz ifadeler için verilen düşük puanlar, olumlu ifadeler için yüksek puanlar anlamına gelmeyebilir (Liu ve Chung, 2017). Bu sebeple, ihtiyaç destekleyici ve engelleyici stillerin birbirinden bağımsız olarak değerlendirilmesi gerekmektedir (Rocchi vd, 2017).

$\mathrm{Bu}$ araştırmanın amacı Liu ve Chung (2017) tarafından öğrencilerin beden eğitimi öğretmenlerinden algıladıkları temel psikolojik ihtiyaç desteğini ölçmek amacıyla geliştirilen Beden Eğitiminde İhtiyaç Destekleyici Öğretim Stili Ölçeğinin Türkçeye uyarlanması ve ölçeğin geçerlik - güvenirliğine ilişkin analizlerin yapılmasıdır.

\section{Yöntem}

\section{Araştırma Modeli}

Araştırma, BEIDÖSÖ'nün Türkçeye uyarlanması, ölçeğin geçerlik - güvenirliğine ilişkin analizlerinin yapılması amacıyla yürütülen metodolojik bir çalışmadır. Araştırma, Muğla Sıtkı Koçman Üniversitesi İnsan Araştırmaları Etik Kurulundan onay (31.05.2018 tarih - 93 sayılı karar) ve Muğla İ̀ Milli Eğitim Müdürlüğü’nden izin alınmıştır (12.10.2018 tarih-70004082-605.01-E.19138502 say1).

\section{Araştırma Grubu}

Araştırma grubunu Muğla'nın farklı ilçelerinde yer alan ortaokullar oluşturmaktadır. Veriler iki ayrı çalışma (Çalışma 1, Çalışma 2) ile toplanmıştır. Çalışma 1'e 4 ortaokuldaki 480 öğrenci, çalışma 2'ye 7 ortaokuldaki 1108 öğrenci katılmıştır. Kayıp verileri olan ölçekler değerlendirmeye alınmamıştır. Bu nedenle Çalışma 1 için 471, Çalışma 2 için 1090 ölçek değerlendirilmiştir. Öğrencilerin yaş ortalamaları

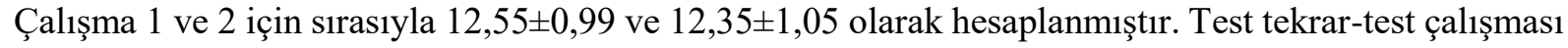
için ölçek, Çalışma 2'de yer alan 400 öğrenciye 2 hafta aradan sonra tekrar uygulanmış ve bu aşamada

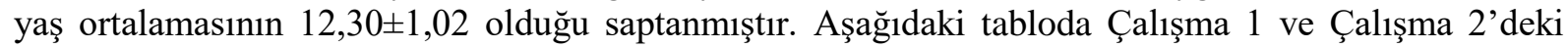
araştırma gruplarına ait veriler yer almaktadır.

Tablo 1.

Katılımcılara Ait Demografik Veriler

\begin{tabular}{|c|c|c|c|c|c|c|c|c|c|c|c|c|}
\hline \multirow[t]{3}{*}{ Sinıf } & \multicolumn{6}{|c|}{ Çalışma 1} & \multicolumn{6}{|c|}{ Çalışma 2} \\
\hline & \multicolumn{2}{|c|}{$\mathbf{K 1 z}$} & \multicolumn{2}{|c|}{ Erkek } & \multicolumn{2}{|c|}{ Toplam } & \multicolumn{2}{|c|}{ Kız } & \multicolumn{2}{|c|}{ Erkek } & \multicolumn{2}{|c|}{ Toplam } \\
\hline & $\mathbf{n}$ & $\%$ & $\mathbf{n}$ & $\%$ & $\mathbf{n}$ & $\%$ & $\mathbf{n}$ & $\%$ & $\mathbf{n}$ & $\%$ & n & $\%$ \\
\hline 6 & 66 & 14,01 & 56 & 11,89 & 122 & 26 & 190 & 17,43 & 163 & 14,96 & 353 & 32,39 \\
\hline 7 & 94 & 19,96 & 86 & 18,26 & 180 & 38 & 188 & 17,25 & 191 & 17,52 & 379 & 34,77 \\
\hline 8 & 85 & 18,04 & 84 & 17,84 & 169 & 36 & 172 & 15,78 & 186 & 17,06 & 358 & 32,84 \\
\hline Toplam & 245 & 52,01 & 226 & 47,99 & 471 & 100 & 550 & 50,46 & 540 & 49,54 & 1090 & 100 \\
\hline
\end{tabular}

Tablo 1'e göre, Çalışma 1'e katılan 122 öğrenci 6. sınıfa, 180 öğrenci 7. sınıfa ve 169 öğrenci 8. sınıfa devam etmektedir. Çalışma 1'deki katılımcıların \%52,01'ini kız, \%47,99'unu erkek öğrenciler oluşturmaktadır. Çalışma 2'ye katılan öğrencilerin 353'ü 6. sınıf, 379'u 7. sinıf ve 358'i 8.sınıf öğrencisidir. Çalışma 2'deki katılımcıların \%50,46'sını kız, \%49,54'ünü erkek öğrenciler oluşturmaktadır. 


\section{Veri Toplama Araçları}

Araştırmada veri toplama aracı olarak araştırmacı tarafından hazırlanan ve öğrencilerin sınıfları, yaşları, cinsiyetleri ve okul takımında yer alıp almama durumları ile ilgili soruları içeren tanımlayıcı bilgi formu, BEIDÖSÖ ve Temel İhtiyaçların Karşılanması Ölçeği kullanılmıştır.

\section{Beden Eğitiminde İhtiyaç Destekleyici Öğretim Stili Ölçeği - BEİDÖSÖ}

Ölçek, öğrencilerin beden eğitimi öğretmenlerinin ihtiyaç destekleyici öğretim stiline ilişkin algılarını ölçmek amacıyla Liu ve Chung (2017) tarafından geliştirilmiştir. Ölçeğin maddeleri, "Teacher as Social Context Questionnaire-TASCQ" ve "Health Care Climate Questionnaire-HCCQ" ölçeklerinden alınan maddelerin bir araya getirilmesiyle oluşturulmuştur. Ölçek oluşturulurken tüm maddelerin olumlu olması istendiği için TASCQ ölçeğinden olumlu olan 13 madde alınmıştır. Bu maddelerin 5'i BÖS, 5'i YDÖS ve 3'ü de ÖDÖS boyutuna aittir. Her alt boyutun aynı sayıda maddeyle temsil edilebilmesi amacıyla HCCQ ölçeğinden ÖDÖS alt boyutu için 2 olumlu madde alınmıştır. Bu sayede her alt boyutta 5 'er madde olmak üzere 3 alt boyut (ÖDÖS-YDÖS-BÖS) ve 15 maddeli ölçek oluşturulmuştur. Tüm maddeler beden eğitimi dersine uyarlanmıştır. Ölçek 7'li derecelendirme sistemiyle (1-Tamamen Katılmıyorum, 7-Tamamen Katılıyorum) değerlendirilmektedir.

Orijinal ölçeğin geliştirilme sürecinde veriler, Hong Kong'da yer alan 3 farklı ortaokulda (7., 8. ve 9. sınıflar) okuyan 605 öğrenciye uygulanmış, tekrar test uygulamasına 178 kişi katılmıştır. Ölçeğin ölçüt bağıntılı geçerliğinin sınanması için Liu ve Chung (2014) tarafından geliştirilen "The Psychological Needs Satisfaction Scale in Physical Education” ölçeği kullanılmıştır. Ölçeğin 15 maddelik orijinal yapısı iyi uyum göstermiş ancak 2-5-9 ve 15. maddelerin çapraz yüklerinin temel yüklerden yüksek olması ve 13. maddede gözlenen düşük faktör yükü $(<0,30)$ sebebiyle bu maddeler ölçekten çıkarılmıştır. Yapılan analiz 10 maddelik ölçeğin daha iyi uyum değerlerine sahip olduğunu göstermiş̧ir. Cronbach Alfa değeri ÖDÖS için 0,76 YDÖS için 0,82 ve BÖS için 0,91 olarak hesaplanmıştır (Liu ve Chung, 2017).

\section{Temel İhtiyaçların Karşılanması Ölçeği (TíKÖ)}

La Guardia, Couchman ve Deci (2000) tarafından öğretmen ve ebeveyn ile ilişkilerde algılanan ihtiyaç doyumunu ölçmek amacıyla geliştirilen ölçek Dost-Gözkan (2016) tarafından Türkçeye uyarlanmıştır. Her alt boyutta 3'er madde olmak üzere 3 alt boyut ve 9 maddeden oluşan ölçek 5'li derecelendirme sistemi ile (1-hiç doğru değil; 5-tamamen doğru) değerlendirilmektedir. Ölçek alt boyutları özerklik "bu derste öğretmenime karşı, kendim gibi olmak konusunda rahat hissederim", yeterlik "bu derste kendimi yetkin/yeterli bir kişi gibi hissederim" ve ilişkili olma "bu derste öğretmenim tarafından sevildiğimi ve kollandığımı hissederim" olarak adlandırılan temel psikolojik ihtiyaçlardan oluşmaktadır.

\section{Çeviri Süreci}

Uyarlama çalışması için öncelikle ölçeği geliştiren araştırmacılardan e-posta yoluyla izin alınmıştır. Ölçek Beaton, Bombardier, Guillemin ve Ferraz (2000) tarafından önerilen yöntemle Türkçeye çevrilmiştir. Bu yönteme göre çeviri süreci 6 aşamadan oluşmaktadır. İlk aşamada ölçek, ikisi spor, ikisi dil alanında uzman olan 4 kişi tarafından birbirinden bağımsız şekilde Türkçeye çevrilmiştir. İkinci aşamada, yapılan çeviriler bir önceki aşamadaki uzmanlara tekrar gönderilmiş, her bir madde için en uygun çeviriyi seçmeleri ve bu çeviriyi puanlamaları istenmiştir. Bu aşama sonrasında ölçek tek bir form (sentez) haline getirilmiştir. Üçüncü aşamada, sentez form, dil alanında çalışan bir uzman tarafından tekrar İngilizceye çevrilmiştir. Dördüncü aşamada, bu aşamaya kadar yapılan tüm çeviriler bir araya getirilerek ölçeğin anlamsal, deyimsel, deneyimsel ve kavramsal açılardan Türkçeye uygunluğu değerlendirilmiştir. Beşinci aşamada ölçek maddelerinin anlaşılır olup olmadığının belirlenmesi için, bir okulun 6, 7 ve 8. sınıfina devam eden, her sinıftan 5'i erkek, 5'i kız toplam 30 ögrenciyle ön-test yapılmıştır. Bu aşamada ölçekte yer alan 4. ifadenin (Öğretmenim devam etmeden önce anladığımdan emin olur) bazı öğrenciler tarafindan anlaşılmaması nedeniyle, bu ifadeye derse kelimesi eklenmiştir (Öğretmenim derse devam etmeden önce anladığımdan emin olur). Bu değişikliğin ardından ölçek son halini almıştır. Son aşamada da şimdiye kadar yapılan çeviri işlemleri ve ölçeğin son hali ölçeğin geliştiricilerine gönderilerek işlemler ve çeviriye ilişkin yazarlardan dönüt alınmıştır. 


\section{Kapsam Geçerliği}

Kapsam geçerliğinin sınanması için uzman görüşüne başvurulmuş, ölçeğin Türkçe formu, beden eğitimi ve spor veya eğitim alanında çalışan ve konuyla ilişkili yayınları bulunan 6 farklı uzmana gönderilmiştir. Uzmanlardan ölçekte yer alan ifadeleri Davis (1992) tekniğine göre 1 (Madde Uygun Değil), 2 (Madde Ciddi Olarak Gözden Geçirilmeli), 3 (Madde Hafifçe Gözden Geçirilmeli) ve 4 (Uygun) olmak üzere puanlamaları istenmiştir.

\section{Verilerin Toplanması}

Veriler 2018-2019 Eğitim-Öğretim Yılı güz yarıyılı Kasım-Ocak ayları arasında iki farklı çalışma ile toplanmıştır. Ölçek verileri, farklı zamanlarda ve farklı katılımcı gruplarına uygulanması halinde aynı sonuçları verip vermediğinin belirlenmesi amacıyla iki ayrı çalışma ile toplanmıştır (Çalışma 1, Çalışma 2). Çalışma 1'de yalnızca BEİDÖSÖ, çalışma 2'de BEIDÖSÖ ve TİKÖ birlikte uygulanmıştır. Uygulama öncesi okul müdürlerine ölçeğin içeriği ve uygulama amacı ile ilgili bilgiler verilmiştir. Daha sonra uygulama için uygun olan sınıflar belirlenmiş ve çalışmanın yapılması için ilgili dersin öğretmeninden izin alınmıştır. Uygulama öncesi öğrencilere çalışmanın amacı ve veri toplama araçları ile ilgili bilgiler verilmiştir. Ölçekler doldurulurken beden eğitimi öğretmenlerinin ortamda olmamasına dikkat edilmiştir.

\section{Verilerin Analizi}

Kapsam geçerliğinin belirlenmesinde Evrensel Anlaşma Hesaplama Yöntemi kullanılmış, ölçekte yer alan her bir madde (I-CVI) ve toplam ölçek (S-CVI) için geçerlik indeksleri hesaplanmıştır. I-CVI değerinin hesaplanması için maddeye 3 veya 4 puan veren uzmanların sayısı belirlenerek bu sayı toplam uzman sayısına bölünmektedir. S-CVI/UA değeri için, uzmanlar tarafından 3 veya 4 puan verilen maddelerin oranı hesaplanmaktadır. S-CVI/Ave değeri ise, ölçek maddelerinin I-CVI puan ortalaması anlamına gelmektedir (Polit ve Beck, 2006).

Elde edilen verilerin analiz edilmesi için SPSS 22.0 ve AMOS 18.0 programları kullanılmıştır. Eksik verileri olan ölçekler temizlendikten sonra betimsel analizler yapılmış, normal dağılımın belirlenmesi için çarpıklık ve basıklık katsayıları incelenmiştir. Ölçeğin yapı geçerliği 1. düzey doğrulayıcı faktör analizi (DFA) kullanılarak test edilmiştir. DFA analizinde maksimum olabilirlik tekniği kullanılmıştır. DFA ile test edilen modelin uyum iyiliği indeksleri hesaplanmıştır. İç tutarlığın saptanması amacıyla Cronbach Alfa $(\alpha)$ ve Bileşik Güvenirlik (Composite Realiability-CR) katsayıları incelenmiştir. Ölçüt bağıntılı geçerliğin test edilmesinde TİKÖ ve güvenirliğin belirlenmesi amacıyla test-tekrar test yöntemi kullanılmış olup elde edilen verilerin analizinde Pearson korelasyon testinden yararlanılmıştır.

\section{Bulgular}

Tablo 2'de uzman görüşlerine göre hesaplanan madde ve ölçek kapsam geçerlik indeksleri yer almaktadır. Buna göre ölçek maddelerine ait madde kapsam geçerlik indeksleri (I- CVI) 0,83 ile 1,0 arasında değişmektedir. Ölçek maddelerinin I- CVI puan ortalamasını gösteren ölçek kapsam geçerlik indeksi (S-CVI/Ave) 0,97 ve evrensel anlaşma hesaplama yöntemi kullanılarak hesaplanan ölçek kapsam geçerlik indeksi (S-CVI/UA) 0,86 olarak belirlenmiştir. 
Tablo 2.

Ölçek ve Madde Kapsam Geçerlik İndeksleri

\begin{tabular}{|c|c|c|c|c|c|c|c|c|}
\hline Madde & Uzman 1 & Uzman 2 & Uzman 3 & Uzman 4 & Uzman 5 & Uzman 6 & Anlaşma Sayısı & I- CVI \\
\hline 1 & 4 & 4 & 4 & 4 & 4 & 3 & 6 & 1 \\
\hline 2 & 4 & 4 & 4 & 4 & 4 & 3 & 6 & 1 \\
\hline 3 & 4 & 4 & 4 & 4 & 4 & 2 & 5 & 0,83 \\
\hline 4 & 4 & 4 & 4 & 4 & 4 & 2 & 5 & 0,83 \\
\hline 5 & 3 & 4 & 4 & 4 & 4 & 4 & 6 & 1 \\
\hline 6 & 4 & 4 & 4 & 4 & 4 & 4 & 6 & 1 \\
\hline 7 & 4 & 4 & 4 & 4 & 4 & 4 & 6 & 1 \\
\hline 8 & 4 & 4 & 4 & 4 & 4 & 4 & 6 & 1 \\
\hline 9 & 4 & 4 & 4 & 4 & 4 & 4 & 6 & 1 \\
\hline 10 & 4 & 4 & 4 & 4 & 4 & 4 & 6 & 1 \\
\hline 11 & 3 & 4 & 4 & 4 & 4 & 3 & 6 & 1 \\
\hline 12 & 4 & 4 & 4 & 4 & 4 & 3 & 6 & 1 \\
\hline 13 & 4 & 4 & 3 & 4 & 4 & 4 & 6 & 1 \\
\hline 14 & 4 & 4 & 4 & 4 & 4 & 4 & 6 & 1 \\
\hline 15 & 3 & 4 & 4 & 4 & 4 & 4 & 6 & 1 \\
\hline Oran & $\% 100$ & $\% 100$ & $\% 100$ & $\% 100$ & $\% 100$ & $\% 86.6$ & $\begin{array}{c}\text { S-CVI/Ave } \\
\text { Toplam Anlaşma } \\
\text { S-CVI/UA }\end{array}$ & $\begin{array}{c}0,97 \\
13 \\
0,86\end{array}$ \\
\hline
\end{tabular}

I-CVI: Madde Kapsam Geçerlik İndeksi (Item Content Validity Index), S-CVI: Ölçek Kapsam Geçerlik İndeksi (Scale Content Validity Index), UA: Evrensel Anlaşma Hesaplama Yöntemi (Universal Agreement Calculation Method)

Tablo 3.

Birinci Düzey Doğrulayıcı Faktör Analizi Uyum Indeksleri

\begin{tabular}{ccccc}
\hline Uyum Ölçütleri & Mükemmel Uyum & Kabul Edilebilir Uyum & Çalışma 1 & Çalışma 2 \\
\hline $\mathbf{X}^{2}$ & $0 \leq \mathrm{X}^{2} \leq 2 \mathrm{df}$ & $2 \mathrm{df} \leq \mathrm{X}^{2} \leq 3 \mathrm{df}$ & 213,54 & 360,61 \\
$\mathbf{X}^{2} /$ df & $0 \leq \mathrm{X}^{2} / \mathrm{df} \leq 2$ & $2 \leq \mathrm{X}^{2} / \mathrm{df} \leq 3$ & 2,48 & 4,24 \\
RMSEA & $0 \leq \mathrm{RMSEA} \leq 0,05$ & $0,05 \leq \mathrm{RMSEA} \leq 0,08$ & 0,05 & 0,05 \\
SRMR & $0 \leq \mathrm{SRMR} \leq 0,05$ & $0,05 \leq \mathrm{SRMR} \leq 0,10$ & 0,02 & 0,03 \\
TLI & $0,97 \leq \mathrm{NNFI} \leq 1,00$ & $0,95 \leq \mathrm{NNFI} \leq 0,97$ & 0,96 & 0,96 \\
CFI & $0,97 \leq \mathrm{CFI} \leq 1$ & $0,95<\mathrm{CFI}<0,97$ & 0,97 & 0,96 \\
\hline
\end{tabular}

Schermelleh-Engel, Moosbrugger ve Müller, 2003

Tablo 3'de yer alan doğrulayıcı faktör analizine göre, her iki çalışma için de $\mathrm{X}^{2}$ değeri anlamlı bulunmuştur $(\mathrm{p}<0,05)$. Çalışma 1 'de $\mathrm{X}^{2} / \mathrm{df}$ oranının 2.48 olduğu, Çalışma 2'de ise 4,24 olduğu belirlenmiştir. Her iki çalışmada da üç alt boyutlu modelin RMSEA $(0,05)$ ve SRMR değerlerinin mükemmel, TLI $(0,96)$ ve CFI değerlerinin ise kabul edilebilir olduğu tespit edilmiştir.

Tablo 4.

Güvenirliğe İlişkin Bulgular

\begin{tabular}{|c|c|c|c|c|}
\hline & \multicolumn{2}{|c|}{ Çalışma 1} & \multicolumn{2}{|c|}{ Çalışma 2} \\
\hline & $\alpha$ & CR & $\alpha$ & CR \\
\hline$Y D O ̈ S$ & 0,86 & 0,86 & 0,84 & 0,84 \\
\hline BÖS & 0,87 & 0,88 & 0,87 & 0,87 \\
\hline$\ddot{O D D O ̈ S}$ & 0,89 & 0,90 & 0,84 & 0,84 \\
\hline Toplam Ölçek & 0,94 & 0,95 & 0,93 & 0,94 \\
\hline
\end{tabular}

Tablo 4'te ölçeğin güvenirliğine ilişkin bulgular yer almaktadır. Buna göre $\alpha$ ve CR katsayılarının Çalışma 1 için 0,86 - 0,90 ve Çalışma 2 için 0,84 - 0,87 arasında değiştiği saptanmıştır. Ölçeğin toplamına ilişkin hesaplanan $\alpha$ katsayısı Çalışma 1 için 0,94 ve Çalışma 2 için 0,93 olarak hesaplanmış, bileşik güvenirlik değeri ise Çalışma 1 için 0,95 ile Çalışma 2 için 0,94 olarak belirlenmiştir. 
Tablo 5.

Ölçeğin Üç Faktörlü Modeline İlişkin Faktör Yapısı

\begin{tabular}{|c|c|c|c|c|c|c|c|c|}
\hline \multirow[t]{3}{*}{ Maddeler } & \multirow{2}{*}{\multicolumn{2}{|c|}{$\begin{array}{c}\text { Ölçüm Hatası } \\
\text { Varyansları }\end{array}$}} & \multicolumn{6}{|c|}{ Madde Faktör Yükleri } \\
\hline & & & \multicolumn{2}{|c|}{$Y D O ̈ S$} & & \multicolumn{2}{|c|}{ ÖDÖS } \\
\hline & Çalışma 1 & Çalışma 2 & Çalışma 1 & Çalışma 2 & Çalışma 1 & Çalışma 2 & Çalışma 1 & Çalışma 2 \\
\hline 1 & 0,49 & 0,59 & 0,70 & 0,63 & & & & \\
\hline 2 & 0,38 & 0,49 & 0,78 & 0,70 & & & & \\
\hline 3 & 0,36 & 0,41 & 0,79 & 0,76 & & & & \\
\hline 4 & 0,49 & 0,47 & 0,71 & 0,72 & & & & \\
\hline 5 & 0,48 & 0,40 & 0,71 & 0,77 & & & & \\
\hline 6 & 0,43 & 0,42 & & & 0,75 & 0,75 & & \\
\hline 7 & 0,47 & 0,51 & & & 0,72 & 0,69 & & \\
\hline 8 & 0,29 & 0,36 & & & 0,83 & 0,79 & & \\
\hline 9 & 0,42 & 0,44 & & & 0,75 & 0,74 & & \\
\hline 10 & 0,38 & 0,36 & & & 0,78 & 0,79 & & \\
\hline 11 & 0,35 & 0,46 & & & & & 0,80 & 0,73 \\
\hline 12 & 0,35 & 0,42 & & & & & 0,80 & 0,76 \\
\hline 13 & 0,37 & 0,49 & & & & & 0,79 & 0,71 \\
\hline 14 & 0,34 & 0,43 & & & & & 0,81 & 0,75 \\
\hline \multirow[t]{2}{*}{15} & 0,34 & 0,53 & & & & & 0,81 & 0,67 \\
\hline & \multicolumn{2}{|c|}{ Skew. } & \multicolumn{6}{|c|}{ Faktör-Faktör Korelasyonları } \\
\hline Faktör & Çalışma 1 & Çalışma 2 & \multirow{2}{*}{\multicolumn{3}{|c|}{ Çalışma 1}} & \multicolumn{3}{|c|}{ Çalışma 2} \\
\hline YDÖS & $-1,03$ & $-0,79$ & & & & & & \\
\hline BöS & $-0,81$ & $-0,65$ & 0,72 & & & $0,68^{*}$ & & \\
\hline ÖDÖS & $-1,10$ & $-0,77$ & 0,79 & & $0,82^{* *}$ & $0,76^{*}$ & & $0,76^{* *}$ \\
\hline
\end{tabular}

Tablo 5 ölçeğin faktör yapısına ait sonuçları göstermektedir. Buna göre madde faktör yüklerinin Çalışma 1'de 0,70 ile 0,83 ve Çalışma 2 'de 0,63 ile 0,79 arasında olduğu belirlenmiştir. Faktör-faktör korelasyonlarına göre ölçek alt boyutları arasında Çalışma 1 için 0,72 ile 0,82 arasında, Çalışma 2 için 0,68 ile 0,76 arasında ilişki bulunmaktadır.

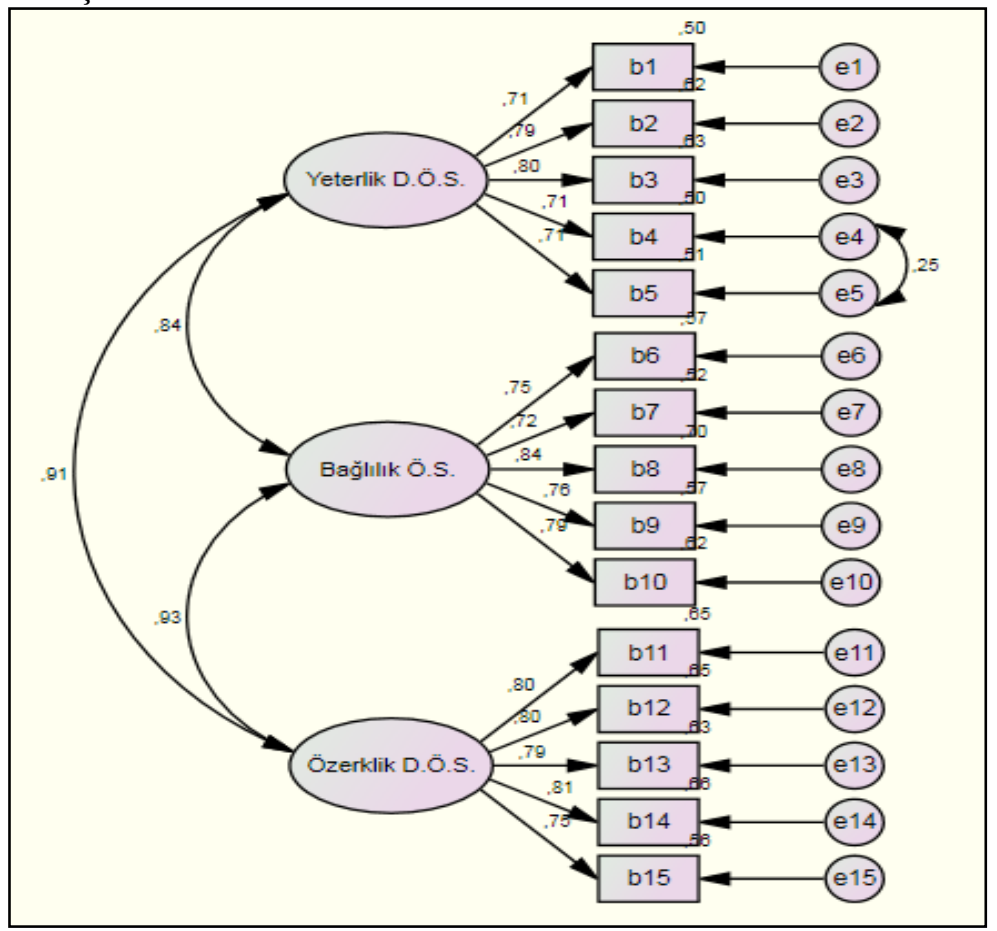

Şekil 1. Ölçeğin Faktör Yapısına İlişkin Kuramsal Model (Çalışma 1)

Şekil 1'de ölçeğin faktör yapısına ilişkin Çalışma 1'e ait DFA sonuçları yer almaktadır. Oluş̧turulan kuramsal modelde ölçüm hataları yüksek bulunan ve birbiriyle ilişkili olduğu düşünülen maddelerde 
(e4-e5) iyileştirme yoluna gidilmiştir. Söz konusu maddeler, aynı alt boyutta (YDÖS) yer almaları nedeniyle birbirine bağlanmıştır.

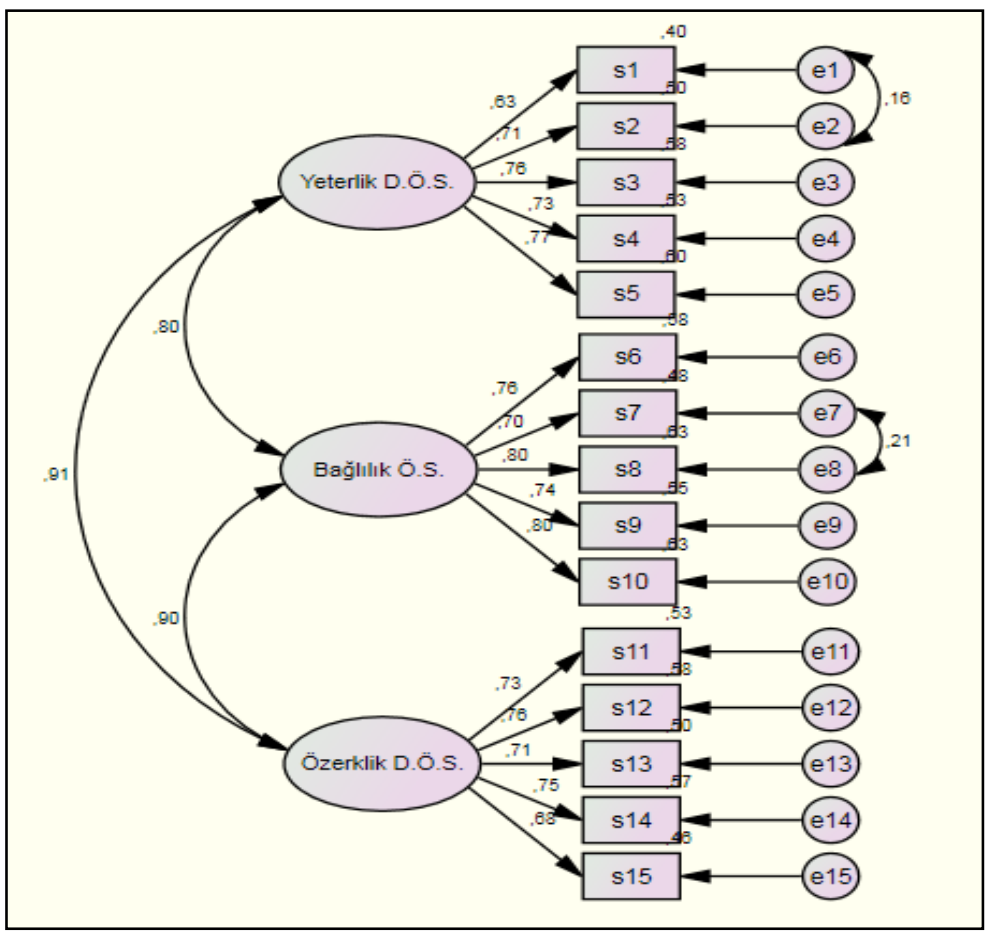

Şekil 2. Ölçeğin Faktör Yapısına İlişkin Kuramsal Model (Çalışma 2)

Şekil 2'de ölçeğin faktör yapısına ilişkin Çalışma 2'ye ait DFA sonuçları yer almaktadır. Oluşturulan kuramsal modelde bazı maddelerin ölçüm hatalarının yüksek olduğu tespit edilmiştir. Bu nedenle birbiriyle ilişkili olduğu düşünülen ve aynı alt boyutta yer alan maddeler (YDÖS alt boyutundaki e1-e2) (BÖS alt boyutundaki e7-e8) birbirine bağlanmıştır.

Tablo 6.

Ölçüt Geçerliğine İliş̧kin Analiz Bulguları

\begin{tabular}{|c|c|c|c|c|}
\hline & 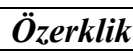 & Yeterlik & İliş̧kili O & тікӧ \\
\hline ÖDÖS & $\mathbf{0 , 4 3}{ }^{* *}$ & $0,36^{* *}$ & $0,51^{* *}$ & $0,53^{* *}$ \\
\hline YDÖS & $0,37^{* *}$ & $0,42^{* *}$ & $0,42^{* *}$ & $0,46^{* *}$ \\
\hline BÖS & $0,42^{* *}$ & $0,37^{* *}$ & $\mathbf{0 , 5 8} 8^{* *}$ & $0,56^{* *}$ \\
\hline BEIDÖSÖ & $0,45^{* *}$ & $0,39^{* * *}$ & $0,55^{* *}$ & $\mathbf{0 , 5 7 ^ { * * }}$ \\
\hline
\end{tabular}

Araştırma sürecinde ölçüt geçerliğinin belirlenmesin amacıyla BEİDÖSÖ, TİKÖ ile ilişkilendirilmiştir. Elde edilen veriler, ölçek alt boyutları arasında pozitif yönde anlamlı ilişkiler olduğunu göstermektedir. Ayrıca toplam ölçek puanlarına bakıldığında iki ölçek arasında da pozitif yönde orta düzeyde ve istatistiksel olarak anlamlı bir ilişki $(0,57)$ olduğu belirlenmiştir.

Tablo 7.

Test-Tekrar Test Güvenirliğine İlişkin Bulgular

\begin{tabular}{lllll}
\hline & BEIDÖSÖ & YDÖS & BÖS & ÖDÖS \\
\hline Pearson korelasyon & $\mathbf{0 , 8 0 * *}$ & $0,69^{* * *}$ & $0,73^{* *}$ & $0,70^{* *}$ \\
Sig. & 0,00 & & & \\
$\mathbf{N}$ & 400 & & & \\
\hline$* * p<0,01$ & & &
\end{tabular}

Tablo 7'de ölçeğin 2 hafta arayla gerçekleştirilen tekrar test sonucuna ait güvenirlik katsayıları yer almaktadır. Buna göre ölçeğin alt boyutları için güvenirlik katsayılarının 0,69 ile 0,73 arasında değiştiği, toplam ölçek güvenirlik katsayısının ise 0,80 olduğu bulunmuştur. Bu sonuçlar, güvenirlik katsayısının alt boyutlar için yeterli ve toplam ölçek için yüksek olduğunu göstermektedir. 


\section{Tartışma, Sonuç ve Öneriler}

$\mathrm{Bu}$ araştırmanın amacı, beden eğitimi öğretmenlerinden algılanan temel psikolojik ihtiyaç desteğinin ölçülmesi için geliştirilen BEIDÖSÖ’nün Türkçeye uyarlanması, ölçeğin geçerlik ve güvenirliğine ilişkin analizlerin yapılmasıdır.

Ölçeğin Türkçeye çevrilmesinden sonra ilk olarak ölçek ve madde kapsam geçerliği incelenmiştir. Literatürde yer alan çalışmalarda I-CVI değerinin 0,80 ve üzerinde olması istenirken (Davis, 1992), Lynn (1986)'e göre bu değer 0.78'den düşük olmamalıdır. Polit, Beck ve Owen (2007) ise altı uzmandan görüş alınması durumunda I-CVI değerinin en az 0,83 olması gerektiğini ifade etmektedir. Ayrıca bu görüşe göre S-CVI/Ave değeri 0,90 'dan S-CVI/UA değeri de 0,70'den yüksek olmalıdır. Kapsam geçerliğine ilişkin veriler Tablo 2'de sunulmuştur. Yapılan hesaplamalar sonucunda madde ve toplam ölçek için kapsam geçerlik indekslerinin literatür ile uyumlu ve istenen değerlerin üzerinde olduğu bulunmuştur. Bu durum; BEİDÖSÖ'nün anlaşılabilir, 6, 7 ve 8 . sınıf düzeyindeki öğrenciler için uygulanabilir olduğunu göstermektedir.

Yap1 geçerliği, test puanlarının veya bu puanlardan yola çıkılarak yapılan değerlendirmelerin ölçülmek istenen yapılarla ne derece ilişkili olduğunun bir göstergesidir (Doğan, 2019) ve istatistiksel olarak faktör analizleri ile test edilmektedir. Faktör analizinde, birbiriyle ilişkili değişkenler bir araya getirilerek daha az sayıda ilişkisiz ve kavramsal açıdan anlamlı yeni değişkenler bulunması amaçlanmaktadır (Bursal, 2019). Faktör analizinin iki türü olan açıklayıcı faktör analizi (AFA) ve DFA yapı geçerliğinin incelenmesinde sıklıkla kullanılmaktadır (Başol, 2016). Hem AFA hem de DFA ortak faktör modeline dayanmakta ve bu nedenle matematiksel olarak benzer prosedürler içermektedir (Harrington, 2009). Ancak AFA çalışmalarında belirgin bir ön beklenti ya da denence yoktur ve ölçeğin faktör yapısı belirlenirken faktör yükleri temel alınmaktadır. DFA'da ise değişkenlerin bir teoriye dayalı olarak önceden belirlenmiş faktörler üzerinde yer alacağı bir öngörünün sinanması söz konusudur (Seçer, 2015b).

DFA ile genellikle gözlenen ve örtük değişkenler arasındaki ilişkilerin test edildiği ölçüm modelleri analiz edilmektedir. Amaç ölçüm modelinin öngörülen kuramsal yapısının toplanan veriler ile doğrulanmasıdır. Ölçüm modeli kavramı, örtük değişkenler ve gözlenen değişkenler arasındaki bağlantıyı ifade etmektedir (Gürbüz, 2019). DFA özellikle ölçüm modelleri yani, gözlenen değişkenler ya da göstergeler ve gizil değişkenler ya da faktörler arasındaki ilişkiler ile ilgilidir. Bu analiz AFA'nın aksine araştırmacının modelin tüm yönlerini önceden belirlemesini gerektirir. Bu nedenle araştırmacı geçmiş teori ve kanıtlara dayalı olarak hangi gözlenen değişkenlerin hangi faktörlerle ilişkili olduğuna ve kaç tane faktör olduğuna ilişkin sağlam bir ön anlayışa sahip olmalıdır. Bunun yanı sıra DFA ile AFA'da bulunmayan başka pek çok analiz (yöntem etkilerinin değerlendirilmesi, faktör modelinin zaman içindeki veya katılımcılar üzerindeki kararlılığının ya da değişmezliğinin incelenmesi) yapılabilmektedir (Brown, 2015). Ayrıca DFA çalışmalarında veri döndürme teknikleri kullanılmamakta, analiz için doğrudan bir çözüm sunulmaktadır (Gorsuch, 2015).

Bir ölçüm aracının geliştirilmesi sırasında ölçeğin temel yapısının ortaya çıkarılması için AFA, önceden geliştirilmiş bir ölçek yapısının yeni bir örneklemde çalışıp çalışmadığının belirlenmesi için DFA kullanılmaktadır (Başol, 2016; Harrington, 2009). DFA aynı zamanda farklı bir dilde geliştirilmiş bir ölçme aracının Türkçeye uyarlanması aşamasında, ölçeğin orijinal yapısının model uyumunun incelenmesinde sıklıkla tercih edilmektedir. Kültürler arası çalışmalarda uyarlanan ölçek zaten test edilmiş ve doğrulanmış bir yapıya sahip olduğu için bu yapıyı yeniden belirlemek (AFA yapmak) yerine toplanan veriler üzerinde DFA yapılması önerilmektedir (Seçer, 2015a). Benzer şekilde çok güçlü bir teorik yapıya sahip yeni bir ölçek geliştiriliyorsa, ilk AFA adımını atlayıp doğrudan DFA yapılması mümkündür (Harrington, 2009).

Yap1 geçerliğinin sınanması için orijinal ölçekte yer alan 3 gizil değişken (ÖDÖS, YDÖS, BÖS) ve 15 gözlenen değişkenden oluşan model için birinci düzey DFA yapılmıştır. Birinci düzey DFA, bir ölçüm aracındaki gözlenen değişkenlerin birden fazla faktör altında toplandığı model olarak adlandırılır ve bu model ölçeğin çok boyutlu olduğu anlamına gelmektedir. Modelde ortak varyansları benzer olan gözlenen değişkenler aynı faktör altında toplanmaktadır. Dolayısıyla aynı faktör altında yer alan maddeler birbirleri ile bağlantılıyken diğer faktörler altındaki değişkenlerden nispeten bağımsızdır (Gürbüz, 2019). Uygulamalı araştırma literatüründeki DFA çalışmalarının büyük çoğunluğu maksimum olabilirlik yöntemiyle yürütülmektedir (Brown, 2015). Bu yöntem; yeterli örneklem büyüklügü, ölçümlerin sürekli değişken olması ve çok değişkenli normallik olmak üzere üç temel varsayıma 
dayanmaktadır (Harrington, 2009). Verilerin normal dağılım gösterip göstermediği, çarpıklık ve basıklık değerleri ile incelenmiştir. Çoğu psikometrik çalışmada \pm 1.0 arasındaki değerler mükemmel kabul edilse de, çalışmaya bağlı olarak \pm 2.0 arasındaki değerin de kabul edilebilir olduğu belirtilmektedir (George ve Mallery, 2020). Buna göre mevcut çalışmadan elde edilen değerler normallik varsayımının karşılandığını göstermektedir.

DFA ile test edilen modelin elde edilen verilerle desteklenip desteklenmediğinin belirlenmesi amaciyla uyum iyiliği indeksleri hesaplanmıştır. Bunun için mutlak uyum indekslerinden ki kare $\left(\mathrm{X}^{2}\right)$, serbestlik derecesi (df), ki karenin serbestlik derecesine oranı $\left(\mathrm{X}^{2} / \mathrm{df}\right)$, yaklaşık hataların ortalama karekökü (RMSEA), standardize edilmiş kök ortalama kare artık (SRMR) değerleri, karşılaştırmalı uyum indekslerinden ise Tucker-Lewis indeksi (TLI) ve karşılaştırmalı uyum indeksi (CFI) değerleri incelenmiştir. $X^{2}$ ile kuramsal olarak önerilen model ile örneklemden elde edilen verilerin uyumu test edilmektedir. Araştırmacı tarafından önerilen model ile veri arasında uyum olması beklendiğinden, bu değerin anlamsız olması gerekir (Gürbüz, 2019). Ancak kovaryans matrislerindeki farkl1lıklar sabit kalsa bile, örneklem büyüklügünün artması, $X^{2}$ değerini de artırmakta, örneklem büyüklüğünün yüksek olması istatistiksel olarak anlamsız bir $\mathrm{X}^{2}$ değeri elde edilmesini zorlaştırmaktadır (Hair, Black, Babin ve Anderson, 2018). Böyle durumlarda modelin uyumunu değerlendirmek için $\mathrm{X}^{2}$ derecesinden ziyade $\mathrm{X}^{2}$ derecesinin serbestlik derecesine oranı ( $\mathrm{X}^{2} / \mathrm{df}$ ) kullanılmaktadır (Meydan ve Şeşen, 2011). RMSEA indeksi, serbestlik derecesini de dikkate alarak modelin örneklem kovaryansıyla ne kadar uyumlu olduğunu test etmektedir. SRMR ile evrene ve örnekleme ait kovaryans matrisleri arasındaki artık kovaryanslar hesaplanmaktadır. TLI değeri, normlaştırılmış uyum indeksinin serbestlik derecesi dikkate alınarak hesaplanmış halidir. CFI ile serbestlik derecesi ve örneklem büyüklügü dikkate alınarak test edilen modelin temel modele göre karşılaştırması yapılır (Gürbüz ve Şahin, 2018). Yapılan çalışmalara göre $\mathrm{X}^{2} / \mathrm{df}$ değerinin 3 ve altında olması modelin iyi uyum gösterdiğini gösterirken, 3-5 arasında olmas1 ise modelin kabul edilebilir olduğu anlamına gelmektedir (Gürbüz, 2019). Ayrıca madde sayıs1 12 ile 30 arasında olup 250'nin üzerinde katılımc1 içeren çalışmalar için $X^{2}$ değerinin anlamlı çıkması beklenirken, CFI ve TLI değerlerinin 0,94'ten büyük, RMSEA değerinin 0,07'den, SRMR değerinin ise 0,08'den küçük olması önerilmektedir (Hair vd, 2018). Çalışma 1 ve Çalışma 2'ye ait uyum iyiliği indeksleri Tablo 3 'te yer almaktadır. Buna göre her iki çalışma için de $\mathrm{X}^{2}$ değeri anlamlı bulunmuştur (p<0,05). $\mathrm{X}^{2} / \mathrm{df}$ değeri çalışma 1 için 2,48 ve çalışma 2 için 4,24 olarak hesaplanmıştır. Her iki çalışmada RMSEA değeri 0,05 bulunurken, TLI değerinin de 0,96 olduğu belirlenmiştir. SRMR değeri ise Çalışma 1 için 0,02 ve Çalışma 2 için 0,03 olarak hesaplanmıştır. CFI değerinin Çalışma 1 için 0,96 ve Çalışma 2 için 0,97 olduğu saptanmıştır. Buna göre her iki çalışma sonucunda gerçekleştirilen DFA ile üretilen uyum iyiliği değerlerine göre ölçeğin genel model uyumunun yeterli olduğu kabul edilmiştir.

Ölçeğin iç tutarlığı $\alpha$ ve CR katsayıları ile incelenmiştir. Psikoloji alanındaki ölçeklerin iç tutarlığına dayanarak güvenilirliğini değerlendiren bir istatistik olan $\alpha$ çok yaygın olarak kullanılmaktadır. Alfa katsayısı 0 ve 1 arasında değer almakta, katsayı 1'e yaklaştıkça ölçekte yer alan maddelerin iç tutarlığının yüksek olduğu sonucuna ulaşılmaktadır. Böyle durumlarda $\alpha$, iç tutarlık katsayısı olarak değil, ögeler arasındaki iç tutarlılığa dayalı bir güvenilirlik tahmini olarak yorumlanmalıdır (Yang ve Green, 2011). Alfa katsayısı hesaplanırken madde yüklerinin eşit (ağırlıksız) olduğu varsayılmaktadır. Ölçeğin madde sayısı ile pozitif ilişkili olması, hesaplamalar açısından sorun oluşturabilmektedir. Çünkü madde sayısının artması güvenirlik katsayısının da artmasına sebep olmaktadır (Hair vd, 2018). Literatürde yer alan çalışmalarda alfa değerinin 0,70 den yüksek olması gerektiği ifade edilmektedir (Büyüköztürk, 2018; Seçer, 2015b; Yaratan, 2017). Genel olarak ölçekte yer alan her alt boyutun da 0,70 düzeyinde iç tutarlığa sahip olması beklenmektedir (Seçer, 2015a). Genellikle yapısal eşitlik modelleriyle birlikte kullanılan CR katsayısı, iç tutarlığın hesaplanmasında $\alpha$ değerine bir alternatif olarak sunulmuştur (Peterson ve Kim, 2013). CR değeri, veri setini en iyi temsil ettiği düşünülen DFA modeline karar verildikten sonra, belirlenen modelden elde edilen her faktör yükleri ve hata varyans1 değerlerine bağlı olarak hesaplanmaktadır (Yang ve Green, 2011). Alfa'nın aksine CR hesaplamalarında madde yüklerinin eşit aralıklı olduğu varsayılmaz. CR değerinin keşfedici çalışmalar için 0,60 ve üzerinde olması beklenirken, genel olarak 0,70-0,95 arasındaki değerlerin uygun olduğu kabul edilmektedir (Hair vd, 2018). Ölçeğin güvenirliğine ait veriler Tablo 4'te sunulmuştur. Buna göre, Çalışma 1 için $\alpha 0,94$ ve CR 0,95 iken, çalışma 2 için bu değerler sırasıyla 0,93 ve 0,94 olarak bulunmuştur. Elde edilen değerler ölçeğin iç tutarlığa sahip olduğunu göstermektedir.

Ölçeğin 3 faktör ve 15 maddeli modeline ilişkin faktör yapısı Tablo 5'te yer almaktadır. Elde edilen veriler madde faktör yüklerinin Çalışma 1 için 0,70 - 0,83 ve Çalışma 2 için 0,63 - 0,79 arasında 
olduğunu göstermektedir. Faktör-faktör korelasyonlarına göre ölçek alt boyutları arasında Çalışma 1 için 0,72 - 0,82 arasında, Çalışma 2 için 0,68 - 0,76 arasında ilişki bulunmaktadır. Bu sonuçlar BEİDÖSÖ'nün alt boyutları arasında Çalışma 1'de yüksek, Çalışma 2'de orta ve yükssek düzeyde ilişki bulunduğunu göstermektedir.

Şekil 1 ve 2'de ölçeğin faktör yapısına ilişkin kuramsal model yer almaktadır. Araştırma süreçlerinde analiz edilen kuramsal modellerin veri ile desteklenmemesi halinde bazı iyileştirme ve değişiklikler yapılarak model iyileştirilmeye çalışılmaktadır. Buradaki amaç, modeldeki uyumsuzluğun tespit edilmesi ve iyileştirmeler yoluyla anlamı ıir modele ulaşılmasıdır (Gürbüz, 2019). Bu aşamada dikkat edilmesi gereken nokta, yalnızca aynı alt boyutta yer alan maddelerde iyileştirmelerin yapılmasıdır (Seçer, 2015b). Araştırmada hem Çalışma 1 hem de Çalışma 2 için oluş̧urulan kuramsal modelde iyileştirmeler yapılmıştır. Çalışma 1 için YDÖS alt boyutundaki maddeler (e4-e5), Çalışma 2 için YDÖS alt boyutundaki (e1-e2) ve BÖS alt boyutundaki (e7-e8) maddeler birbirine bağlanmıştır.

Ölçüt bağıntılı geçerliğin test edilmesinde TİKÖ kullanılmış, elde edilen veriler Pearson korelasyon testi kullanılarak değerlendirilmiştir. Ölçüt geçerliğine ilişkin analiz bulguları Tablo 6'da verilmiştir. Analiz sonucunda BEİDÖSÖ ve TİKÖ arasında pozitif yönde orta düzeyde istatistiksel olarak anlamlı ilişki olduğu bulunmuştur (r: $0,57 \mathrm{p}<0,01)$. Ölçek alt boyutları arasında da orta seviyede pozitif yönde anlamlı ilişkiler bulunmuştur. ÖDÖS ile özerklik ihtiyaç doyumu arasında (r: 0,57 p<0,01), YDÖS ile yeterlik ihtiyaç doyumu arasında (r: $0,42 \mathrm{p}<0,01)$ ve BÖS ile ilişkili olma ihtiyaç doyumu arasında (r: 0,58 $\mathrm{p}<0,01)$ orta düzeyde istatistiksel olarak anlamlı ilişkiler olduğu saptanmıştır. Buna göre algılanan ihtiyaç desteğinin artması, ihtiyaç doyumunu da olumlu etkilemektedir.

Çalışmada ölçek güvenirliğinin belirlenmesi için test-tekrar test yöntemi kullanılmış ve veriler Pearson korelasyon testi kullanılarak değerlendirilmiştir. Test-tekrar test, ölçme aracının kararlılık gösterip göstermediğinin belirlenmesine imkân sağlamaktadır (Seçer, 2015a). Test sonucu elde edilen değerin 1'e yaklaşması uygulamalar arası puanların birbirine yaklaştı̆̆ını göstermektedir (Büyüköztürk, Çakmak, Akgün, Karadeniz ve Demirel, 2016). Tekrar test çalışmalarında güvenirlik testinden elde edilen değerin en az 0,70 olması beklenmektedir (Başol, 2016). Araştırmanın test-tekrar test güvenirliğine ait bulgular Tablo 7'de yer almaktadır. Buna göre, ölçek güvenirlik katsayısı 0,80 olarak hesaplanmıştır. Bu değer, yeterlik desteği için 0,69 bağl1lık için 0,73 ve özerklik desteği için 0,70 olarak belirlenmiştir. Bulgular, ölçeğin test-tekrar test güvenirlik katsayılarının alt boyutlar için yeterli ve toplam ölçek için yüksek olduğunu göstermektedir.

Sonuç olarak; BEİDÖSÖ üç faktör ve 15 maddeden oluşan orijinal yapısını korumaktadır. Elde edilen veriler, ölçeğin ortaokul 6,7 ve 8 . sınıf öğrencilerinin beden eğitimi öğretmenlerinden algıladıkları ihtiyaç destekleyici öğretim stilini ölçmede kullanılabilecek geçerli ve güvenilir bir ölçme aracı olduğunu göstermektedir.

Araştırmadan elde edilen bulgular kapsamında aşağıdaki öneriler sunulmuştur;

BEİDÖSÖ’nün farklı okul türlerinde test edileceği çalışmalar planlanabilir. Bu çalışmalarda öğretim stili ile öğrenci algılarını etkilemesi muhtemel değişkenlere (sınıf mevcudu, öğretmenin yaşı, cinsiyeti vb.) yer verilebilir. Ölçek, öğretim stillerine ilişkin öğrenci algılarının zaman içinde nasıl değiştiğinin belirlenmesi için müdahale içeren çalışmalarda kullanılabilir. Algılanan ihtiyaç desteğinin yüksek çıktığı yerlerde çalışan öğretmenlerin kullandıkları öğretim stillerine ilişkin araştırmalar planlanabilir. Algılanan ihtiyaç desteğinin düşük çıkması durumunda bu öğretmenler için hizmet içi eğitimler düzenlenebilir. Ölçek, motivasyon, okula bağl1lık, fiziksel aktiviteye katılım gibi özellikleri ölçen ölçme araçları ile birlikte kullanılarak, algılanan ihtiyaç destekleyici öğretim stilinin bu özelliklerle ilişkisi incelenebilir. Ölçek, yalnızca öğrenci beyanlarına dayalı sonuçları göstermektedir. Algılanan ihtiyaç destekleyici öğretim stilini belirlemek amacıyla, ölçekle birlikte ders gözlem formları kullanılabilir. 


\section{Kaynakça}

Acar, Z. (2012). İlköğretim öğrencilerinin beden ĕgitimi ve ders dışı etkinliklere katılım motivasyonlarının incelenmesi. (Yayımlanmamış yüksek lisans tezi). Ankara Üniversitesi, Ankara.

Aelterman, N., Vansteenkiste, M., Van den Berghe, L., De Meyer, J. \& Haerens, L. (2014). Fostering a need-supportive teaching style: Intervention effects on physical education teachers' beliefs and teaching behaviors. Journal of Sport and Exercise Psychology, 36(6), 595-609.

Bailey, R., Cope, E. J. \& Pearce, G. (2013). Why do children take part in, and remain involved in sport? A literature review and discussion of implications for sports coaches. International Journal of Coaching Science, 7(1), 56-75.

Bartholomew, K. J., Ntoumanis, N. \& Th $\oslash$ gersen-Ntoumani, C. (2009). A review of controlling motivational strategies from a self-determination theory perspective: Implications for sports coaches. International Review of Sport and Exercise Psychology, 2(2), 215-233.

Başol, G. (2016). Ĕ̆itimde ölçme ve değerlendirme. Pegem Atıf İndeksi.

Bayrakdar, A. (2010). Çocuklarda fiziksel aktivite düzeyleri ve beden kitle indeksinin değerlendirilmesi. (Yayımlanmamış yüksek lisans tezi). Muğla Sitkı Koçman Üniversitesi, Muğla.

Brown, T. A. (2015). Confirmatory factor analysis for applied research. Guilford Publications.

Bursal, M. (2017). SPSS ile temel veri analizleri. An1 Yayıncılık.

Büyüköztürk, Ş. (2018). Sosyal bilimler için veri analizi el kitabı. Pegem Atıf İndeksi.

Büyüköztürk, Ş., Çakmak, E. K., Akgün, Ö. E., Karadeniz, Ş. ve Demirel, F. (2016). Bilimsel araştırma yöntemleri. Pegem Akademi.

Cañabate, D., Colomer, J., \& Serra, T. (2018). Pre-service teachers' reflective narratives on cooperative learning: configurations of need-supportive teaching in higher education. In INTED2018 Proceedings (pp. 4017-4021). IATED.

Chua, S. N., Wong, N. \& Koestner, R. (2014). Autonomy and controlling support are two sides of the same coin. Personality and Individual Differences, 68, 48-52.

Cihangir-Çankaya, Z. (2005). Öz belirleme modeli: Özerklik desteği, ihtiyaç doyumu ve iyi olma. (Yayımlanmamış yüksek lisans tezi). Gazi Üniversitesi, Ankara.

Curran, T. \& Standage, M. (2017). Psychological needs and the quality of student engagement in physical education: Teachers as key facilitators. Journal of Teaching in Physical Education, $36(3), 262-276$.

Davis, L. (1992). Instrument review: Getting the most from your panel of experts. Applied Nursing Research, 5, 104-107.

De Meyer, J., Tallir, I. B., Soenens, B., Vansteenkiste, M., Aelterman, N., Van den Berghe, L., Speleers, L. \& Haerens, L. (2014). Does observed controlling teaching behavior relate to students' motivation in physical education?. Journal of Educational Psychology, 106(2), 541.

Deci, E. L. \& Ryan, R. M. (2008). Facilitating optimal motivation and psychological well-being across life's domains. Canadian Psychology/Psychologie canadienne, 49(1), 14-23.

Deci, E. L. \& Ryan, R. M. (2016). Optimizing students' motivation in the era of testing and pressure: A self-determination theory perspective. Liu, W. C., Wang, J. C. K., \& Ryan, R. M. (Eds.). In Building autonomous learners (pp. 9-29). Springer.

Deci, E. L., \& Ryan, R. M. (1985). Self-determination and intrinsic motivation in human behavior. Springer.

Deci, E. L., \& Ryan, R. M. (2012). Motivation, personality, and development within embedded social contexts: An overview of self-determination theory. In R. M. Ryan (Eds.), Oxford library of psychology. The Oxford handbook of human motivation (p. 85-107). Oxford University Press.

Doğan, N. (2019). Ĕgitimde Ölçme ve Değerlendirme. Pegem Akademi Yayınc1lık.

Dost-Gözkan, A. (2016). Ergenlerin-ebeveynleri ile bilgi paylaşma davranışı: Bireye ve aileye ilişskin belirleyici faktörler ve olumlu gelişim. Tübitak proje \#115K324, yayınlanmamış pilot çalışma.

Elliot, A. J., Dweck, C. S., \& Yeager, D. S. (Eds.). (2017). Handbook of competence and motivation: Theory and application. Guilford Publications.

Erkuş, A. (2019). Davranış bilimleri için bilimsel araştırma süreci. Ankara: Seçkin. 
Esen, G. (2010). Illköğretim okulları 2. kademe öğrencilerinin beden eğitimi dersine ve ders dişı spor etkinliklerine yönelik tutumlarında beden eğitimi öğretmenlerinin rolü. (Yayımlanmamış yüksek lisans tezi). Marmara Üniversitesi, İstanbul.

Furrer, C., \& Skinner, E. (2003). Sense of relatedness as a factor in children's academic engagement and performance. Journal of Educational Psychology, 95(1), 148-162.

George, D., \& Mallery, P. (2020). IBM SPSS statistics 26 step by step: A simple guide and reference. Routledge.

Gorsuch, R. L. (2015). Factor Analysis: Classic Edition. Routledge.

Güneş, A. (2004). Okullarda beden eğitimi ve oyun öğretimi. Pegem Akademi Yayıncılık.

Gürbüz, S. (2019). AMOS ile yapısal eşitlik modellemesi. Seçkin Yayıncılık.

Gürbüz, S. ve Şahin, F. (2018). Sosyal bilimlerde araştırma yöntemleri: Felsefe-yöntem-analiz. Seçkin Yayincilik.

Haerens, L., Vansteenkiste, M., De Meester, A., Delrue, J., Tallir, I., Vande Broek, G., Goris, W. \& Aelterman, N. (2018). Different combinations of perceived autonomy support and control: Identifying the most optimal motivating style. Physical Education and Sport Pedagogy, 23(1), 16-36.

Hagger, M. S., \& Chatzisarantis, N. L. (2007). Intrinsic motivation and self-determination in exercise and sport. Human Kinetics.

Hair, J. F., Black, W. C., Anderson, R. E., \& Babin, B. J. (2018). Multivariate data analysis. Cengage Learning EMEA.

Harrington, D. (2009). Confirmatory factor analysis. Oxford University Press.

Hastie, P. A., Rudisill, M. E., \& Wadsworth, D. D. (2013). Providing students with voice and choice: lessons from intervention research on autonomy-supportive climates in physical education. Sport, Education and Society, 18(1), 38-56.

Jang, H., Reeve, J. ve Deci, E. L. (2010). Engaging students in learning activities: It is not autonomy support or structure but autonomy support and structure. Journal of educational psychology, $102(3), 588-600$.

Kandemirci, D. (2018). Sınıf öğretmenlerine yönelik özerklik desteği eğitim programının etkililiğinin incelenmesi. (Yayınlanmamış Doktora Tezi). Ege Üniversitesi, İzmir.

La Guardia, J. G., Couchman, C. E. \& Deci, E. (2000). Within-person variation in security of attachment: A self-determination theory perspective on attachment, need fulfillment, and well-being. Journal of Personality and Social Psychology, 3, 367-384.

Leenknecht, M. J., Wijnia, L., Loyens, S. M. \& Rikers, R. M. (2017). Need-supportive teaching in higher education: Configurations of autonomy support, structure, and involvement. Teaching and Teacher Education, 68, 134-142.

Li, C., Kee, Y. H., Kong, L. C., Zou, L., Ng, K. L., \& Li, H. (2019). Autonomy-supportive teaching and basic psychological need satisfaction among school students: The role of mindfulness. International journal of environmental research and public health, 16(14), 2599.

Liu, J. D. \& Chung, P. K. (2014). Development and initial validation of the psychological needs satisfaction scale in physical education. Measurement in Physical Education and Exercise Science, 18(2), 101-122.

Liu, J. D. \& Chung, P. K. (2017). Factor structure and measurement invariance of the Need-Supportive Teaching Style Scale for Physical Education. Perceptual and Motor Skills, 124(4), 864-879.

Liu, J., Bartholomew, K., \& Chung, P. K. (2017). Perceptions of teachers' interpersonal styles and wellbeing and ill-being in secondary school physical education students: The role of need satisfaction and need frustration. School Mental Health, 9(4), 360-371.

Liu, W. C., Wang, J. C. K. \& Ryan, R. M. (2016). Understanding motivation in education: theoretical and practical considerations. Liu, W. C., Wang, J. C. K., \& Ryan, R. M. (Eds.). In Building autonomous learners (pp. 1-7). Springer, Singapore.

Lynn, M. R. (1986). Determination and quantification of content validity. Nursing research.

Memduhoğlu, H. B., Yılmaz, K. (2019). Eğitime giriş. Pegem Akademi Yayıncılık.

Mercier, K., Donovan, C., Gibbone, A., \& Rozga, K. (2017). Three-year study of students' attitudes toward physical education: grades 4-8. Research quarterly for exercise and sport, 88(3), 307315.

Meydan, C. H. ve Şeşen, H. (2011). Yapısal eşitlik modellemesi AMOS uygulamaları. Detay Yayıncılık. 
Niemiec, C. P., Soenens, B., \& Vansteenkiste, M. (2014). Is relatedness enough? On the importance of need support in different types of social experiences. Weinstein N. (Eds.). In Human motivation and interpersonal relationships (pp. 77-96). Springer, Dordrecht.

Orhan, R. ve Yoncalık, O. (2016). Türkiye'deki ortaokul öğrencilerinin beden eğitimi ve spor alışkanlıkları. Kırıkkale Üniversitesi Sosyal Bilimler Dergisi, 6(1), 353-376.

Otundo, J. O., \& Garn, A. C. (2019). Student interest and engagement in middle school physical education: Examining the role of needs supportive teaching. International Journal of Educational Psychology, 8(2), 137-161.

Peterson, R. A. \& Kim, Y. (2013). On the relationship between coefficient alpha and composite reliability. Journal of Applied Psychology, 98(1), 194- 198.

Polit, D. F. \& Beck, C. T. (2006). The content validity index: are you sure you know what's being reported? Critique and recommendations. Research in nursing \& health, 29(5), 489-497.

Polit, D. F., Beck, C. T., \& Owen, S. V. (2007). Is the CVI an acceptable indicator of content validity? Appraisal and recommendations. Research in Nursing \& Health, 30(4), 459-467.

Reeve, J. (2012). A self-determination theory perspective on student engagement. Christenson, S. L., Reschly, A. L. \& Wylie C. (Eds). In Handbook of research on student engagement (pp. 149-172). Springer.

Reeve, J. \& Jang, H. (2006). What teachers say and do to support students' autonomy during a learning activity. Journal of educational psychology, 98(1), $209-218$.

Rocchi, M., Pelletier, L., Cheung, S., Baxter, D., \& Beaudry, S. (2017). Assessing need-supportive and need-thwarting interpersonal behaviours: The Interpersonal Behaviours Questionnaire (IBQ). Personality and Individual Differences, 104, 423-433.

Ryan, R. M. \& Deci, E. L. (2017). Self-determination theory: Basic psychological needs in motivation, development, and wellness. Guilford Publications.

Ryan, R. M., \& Deci, E. L. (2007). Active human nature: Self-determination theory and the promotion and maintenance of sport, exercise, and health. Hagger, M. S., \& Chatzisarantis, N. L. D. (Eds.). Intrinsic motivation and self-determination in exercise and sport (pp. 1-19). Human Kinetics.

Schermelleh-Engel, K., Moosbrugger, H. \& Müller, H. (2003). Evaluating the fit of structural equation models: Tests of significance and descriptive goodness-of-fit measures. Methods of Psychological Research Online, 8(2), 23-74.

Seçer, İ. (2015a). Psikolojik test geliştirme ve uyarlama süreci: SPSS ve LISREL uygulamaları. Anı yayincilik.

Seçer, İ. (2015b). SPSS ve LISRELL ile pratik veri analizi: Analiz ve raporlaştırma. Anı Yayıncılık.

Seifert, K., \& Sutton, R. (2009). Educational psychology. Switzerland: The Global Text Project.

Skinner, E. A. \& Belmont, M. J. (1993). Motivation in the classroom: Reciprocal effects of teacher behavior and student engagement across the school year. Journal of educational psychology, 85(4), 571-581.

Stroet, K., Opdenakker, M. C. \& Minnaert, A. (2015). Need supportive teaching in practice: a narrative analysis in schools with contrasting educational approaches. Social Psychology of Education, $18(3), 585-613$.

Stroet, K., Opdenakker, M. C., \& Minnaert, A. (2013). Effects of need supportive teaching on early adolescents' motivation and engagement: A review of the literature. Educational research review, 9, 65-87.

Subramaniam, P. R. ve Silverman, S. (2007). Middle school students' attitudes toward physical education. Teaching and teacher education, 23(5), 602-611.

Tekinalp, B. E. ve Terzi, Ş. I. (2015). Ĕgitimde pozitif psikoloji uygulamaları. Pegem Akademi.

Van den Berghe, L., Cardon, G., Tallir, I., Kirk, D., \& Haerens, L. (2016). Dynamics of need-supportive and need-thwarting teaching behavior: The bidirectional relationship with student engagement and disengagement in the beginning of a lesson. Physical Education and Sport Pedagogy, 21(6), 653-670.

van Dongen, B., Finn, T., Hansen, V., Wagemakers, A., Lubans, D., \& Dally, K. (2018). The ATLAS school-based health promotion programme: Does a need-supportive learning context help to motivate adolescent boys?. European Physical Education Review, 24(3), 330-348.

Weinstein, N., \& DeHaan, C. R. (2014). On the mutuality of human motivation and relationships. Weinstein N. (Eds.). In Human Motivation and Interpersonal Relationships (pp. 3-25). Springer. 
Yang, Y. \& Green, S. B. (2011). Coefficient alpha: A reliability coefficient for the 21st century?. Journal of Psychoeducational Assessment, 29(4), 377-392.

Yaratan, H. (2017). Sosyal Bilimler İçin Temel İstatistik SPSS Uygulamalı. Anı Yayıncılık.

Y1ldırım, E. (2017). İstatistiksel Araştırma Yöntemleri Su Tüketim Bilinci Üzerine Bir Kamuoyu Araştırması. Ankara, Seçkin Yayınevi.

Zencirkıran, M. (2017). Davranış bilimleri. Dora.

\section{Extended Abstract}

\section{Introduction}

The most important factor affecting learning in the education process is the way teachers communicate with students (Ryan \& Deci, 2017). In recent years, teachers' interpersonal communication styles and behaviours have been examined from the Self-Determination Theory framework (Liu \& Chung, 2017). At the basis of the theory, there are three basic psychological needs which are called autonomy, competence and relatedness. According to SDT, the most important point of individual development is meeting these basic psychological needs (Cihangir-Çankaya 2005). Therefore, it is important to arrange educational environments to meet these needs (Ryan \& Deci, 2017). To the theory, there are three need supportive and three need thwarting teaching styles in the educational environment. These are called as autonomy supportive - controlling, competence supportive - competence thwarting and relatedness supportive - relatedness thwarting teaching styles (Skinner and Belmont, 1993).

When the basic psychological needs which are important for psychological health and well-being are supported, individuals become more organized and integrated. If these needs are not satisfied or thwarted, various negative results occur (Weinstein \& DeHaan, 2014). Therefore, it is thought that determining students' perceptions of need-supportive teaching style is very important. The aim of this research was to adapt the Need-Supportive Teaching Style Scale in Physical Education; NSTSSPE to Turkish, which was developed by Liu and Chung (2017) to measure students' perceptions of teachers' need-supportive teaching style in physical education classes and to analyse of the scale's validity and reliability.

\section{Method and Results}

Data for this methodological study was collected between November and January 2018-2019 academic year. For data collection two study were conducted (Study 1, Study 2). After the missing data were deleted, 471 scale in Study 1 (mean age: $12.55 \pm 0.99$ ) and 1090 scale in Study 2 (mean age: $12.35 \pm$ 1.05 ) were evaluated. For test-retest study, the scale was reapplied to 400 students (mean age: $12.30 \pm$ 1.02) in Study 2 after 2 weeks.

In the research, descriptive information form, NSTSSPE and Basic Psychological Needs Scale (BPNS) were used as data collection tools. NSTSSPE was developed by Liu and Chung (2017) to measure students' perceptions of physical education teachers' needs supportive teaching style. The scale consists of 3 sub-dimensions and 15 items. The scale is a 7-point Likert type, scored between 1 (strongly disagree) and 7 (strongly agree). BPNS was developed by La Guardia et al. (2000) in order to measure the perceived need satisfaction in relations with teachers and parents and adapted to Turkish by DostGözkan (2016). The scale is 5-point Likert type (1-not true at all; 5-completely accurate) and consists of 3 sub-dimensions and 9 items.

For adaptation process, first, permission was obtained from the researchers who developed the scale via e-mail. The scale was translated into Turkish by the method proposed by Beaton et al. (2000). After the translations were made, the scale was sent to 6 different experts to test the content validity. Experts were asked to score the items on the scale from 1 (Item Not Suitable) to 4 (Appropriate). Universal Agreement Calculation Method was used to determine the content validity. Validity indices were calculated for each item (I-CVI) and total scale (S-CVI) in the scale. The I-CVI was found between 0.83 and 1. S-CVI/Ave was determined to be 0.97 and S-CVI/UA value was calculated as 0.86 . These findings showed that content validity indexes are sufficient for each item and total scale.

The obtained data were analysed in SPSS 22.0 and AMOS 18.0 programs. The construct validity of the scale was tested using 1 . level confirmatory factor analysis (CFA). In order to determine whether the model tested with CFA is supported by the obtained data, $\mathrm{X}^{2}, \mathrm{df}, \mathrm{X}^{2} / \mathrm{df}, \mathrm{RMSEA}$, SRMR, TLI and CFI goodness of fit indices were examined. The $\mathrm{X}^{2} / \mathrm{df}$ value was calculated as 2.48 for study 1 and 4.24 for 
study 2. In both studies, RMSEA value was found to be 0.05 and TLI value was determined to be 0.96 . The SRMR value was calculated as 0.02 for Study 1 and 0.03 for Study 2. The CFI value was found to be 0.96 for Study 1 and 0.97 for Study 2. These results show that the general model fit of the scale is sufficient.

In order to determine the internal consistency, Cronbach Alpha $(\alpha)$ and composite reliability (CR) coefficients were examined. For both study $\alpha$ and CR values were found to be high (Study 1 and $2 \alpha$ : 0.94 and 0.93 , Study 2: CR 0.95 and 0.94 respectively). The obtained results show that the scale has internal consistency. BPNS was used to test the criterion validity. The data were evaluated with Pearson correlation test. As a result of the test, a moderate statistically significant relationship was found between NSTSSPE and BPNS $(r=0.57, \mathrm{p}<0.01)$. According to this, perceived need support is related to need satisfaction. In the study, to determine reliability test-retest method was used and data were evaluated with Pearson correlation test. The scale reliability coefficient was calculated as 0.80 . This value was found to be 0.73 for competence support and 0.73 for commitment and 0.70 for autonomy support. These results showed that the retest reliability coefficients of the scale are sufficient.

\section{Conclusions}

As a result, NSTSSPE maintains its original structure consisting of three factors and 15 items. The obtained data shows that the scale is a valid and reliable measurement tool that can be used to measure the middle school students' perception of teachers' need-supportive teaching style in physical education classes.

\section{Beden Eğitiminde İhtiyaç Destekleyici Öğretim Stili Ölçeği}

\begin{tabular}{|c|c|c|c|c|c|c|c|c|}
\hline & & 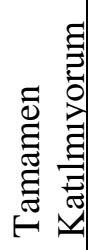 & 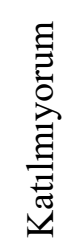 & 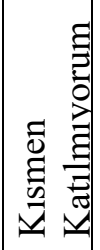 & 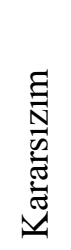 & 章 & 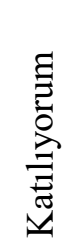 & 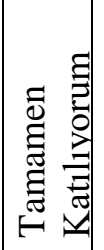 \\
\hline 1 & $\begin{array}{l}\text { Öğretmenim derste benden ne beklediğini her zaman } \\
\text { açıkça belirtir. }\end{array}$ & & & & & & & \\
\hline 2 & $\begin{array}{l}\text { Öğretmenim problemleri kendi kendime nasıl } \\
\text { çözeceğimi gösterir. }\end{array}$ & & & & & & & \\
\hline 3 & $\begin{array}{l}\text { Eğer bir problemi çözemezsem, ögretmenim bana } \\
\text { denemem için farklı yollar gösterir. }\end{array}$ & & & & & & & \\
\hline 4 & $\begin{array}{l}\text { Öğretmenim derse devam etmeden önce } \\
\text { anladığımdan emin olur. }\end{array}$ & & & & & & & \\
\hline 5 & $\begin{array}{l}\text { Öğretmenim yeni bir konuya geçmeden önce hazır } \\
\text { olup olmadı̆ımı kontrol eder. }\end{array}$ & & & & & & & \\
\hline 6 & Öğretmenim beni sever. & & & & & & & \\
\hline 7 & Öğretmenim benimle zaman geçirir. & & & & & & & \\
\hline 8 & Öğretmenim beni gerçekten önemser. & & & & & & & \\
\hline 9 & Öğretmenim beni iyi tanır. & & & & & & & \\
\hline 10 & Öğretmenim benimle konuşur. & & & & & & & \\
\hline 11 & Öğretmenim tarafından anlaşıldığımı hissederim. & & & & & & & \\
\hline 12 & $\begin{array}{l}\text { Öğretmenim bir şey yapmak için yeni yollar } \\
\text { önermeden önce benim nasıl öğrendiğimi anlamaya } \\
\text { çalışır. }\end{array}$ & & & & & & & \\
\hline 13 & Öğretmenim bana çok sayıda seçenek sunar. & & & & & & & \\
\hline 14 & Öğretmenim benim fikirlerimi dinler. & & & & & & & \\
\hline 15 & $\begin{array}{l}\text { Öğretmenim okulda öğrendiğimiz şeyleri nasıl } \\
\text { kullanacağım hakkında bilgi verir. }\end{array}$ & & & & & & & \\
\hline
\end{tabular}


* Bu makaleye 1. Yazar \%60; 2. Yazar \%40 oranında katkıda bulunmuştur.

**Araştırma, Muğla Sıtkı Koçman Üniversitesi İnsan Araştırmaları Etik Kurulundan onay (31.05.2018 tarih- 93 sayılı karar) ve Muğla İl Milli Eğitim Müdürlüğü’nden izin alınmıştır (12.10.2018 tarih-70004082-605.01E.19138502 say1). 